\title{
Crises and social policy preferences: The impact of Covid-19 in Britain*
}

\author{
Anja Neundorf \\ Sergi Pardos-Prado ${ }^{\dagger}$ \\ (University of Glasgow) \\ (University of Glasgow)
}

December 9, 2021

\begin{abstract}
Do crises substantially change public support for taxes and spending, and why? We leverage the multifaceted character of the Covid-19 pandemic to test different theoretical micromechanisms usually confounded in observational research, or tested in isolation. Our randomized survey experiment provides four main findings. First, the economic and health dimensions of the crisis generated a substantial left-wing turn among the British public. Second, the effects are stronger on spending priorities (unemployment and health policies) than on who should pay for the welfare bill (progressivity of income and wealth taxes). Third, economic self-interested motivations are not relevant mechanisms to explain our findings. Fourth, framings associated with open borders and the global spread of the virus polarized welfare attitudes along immigration policy preferences. The generalizability of our findings, the prospects of redistributive conflicts after Covid, and the validity of established theories of welfare preferences in times of crisis are discussed.
\end{abstract}

Keywords: Covid-19; taxing; spending; preferences; survey experiment; crisis.

\footnotetext{
* This research was generously funded by the British Academy. Previous version of this paper were presented at the "Governments, Parties and Elections Online Seminar" at Liverpool University (March 2021) and the 2021 Annual Meeting of the American Political Science Association (Oct 2021).

† Email: anja.neundorf@glasgow.ac.uk; sergi.pardos-prado@glasgow.ac.uk
} 


\section{Introduction}

What is the effect of crises on public preferences for taxing and spending? Previous work on this topic has come up with conflicting results, and has not always focused on causal mechanisms. On the one hand, shocks have been suggested to dampen support for redistribution (Durr, 1993; Stevenson, 2001), especially if they induce aggregate economic inequality (Kelly and Enns, 2010). On the other hand, however, economic contractions can also shift citizens to the left of the ideological spectrum and increase pro-welfare attitudes (Blekesaune, 2007; Naumann et al., 2016; Limberg, 2020; Wlezien and Soroka, 2021), even if only in the short term (Margalit, 2013, 2019).

The Covid-19 pandemic has been an unprecedented global shock affecting different social and economic risks at once. Those include staggering macro-economic contractions and debt accumulation not seen since WWII, widespread health hazards, controversies over border control and the risk of global travel routes, and public confidence in political competence. The exogenous and multifaceted character of the Covid-19 pandemic allows us to unpack the theoretical micro mechanisms connecting hypothetical aspects of a given crisis with preferences for taxing and spending.

In this paper we present a survey experiment randomly assigning respondents to different informational treatments connected with the Covid-19 crisis, before asking them about preferences for unemployment spending, public health spending, income tax progressivity, and a wealth tax. The advantage of focusing on a global pandemic is that we can credibly manipulate the saliency of different theoretical drivers of preferences that are typically confounded in observational research, or difficult to analyze together. Our informational treatments are designed to test sociotropic macro-economic considerations (Duch and Stevenson, 2008), income-maximising motivations (Kenworthy and Pontusson, 2005), labormarket risks (Rehm, 2009), other-regarding preferences associated with the risk of open borders (Cavaille and Trump, 2015; Rueda, 2017), and governmental performance (Green and Jennings, 2017).

Our pre-registered experiment, fielded in Great Britain in February 2021, shows four main results. First, the economic and health dimensions of the crisis had a substantial average impact on increased preferences for spending on public health and unemployment benefits. Second, the effects of the pandemic on preferences for tax progressivity and a wealth tax are weaker: only the health dimension of 
the crisis marginally increases preferences for income tax progressivity, and we do not find evidence of a widespread shift in favor of taxing wealth as a result of the pandemic. Third, economic self-interested motivations are not relevant mechanisms to explain our findings. Our treatment effects are similar among rich and poor households, and did not increase insurance demands against individual exposure to unemployment risk. The mechanism behind our findings is rather socio-tropic: a generalized average reaction against a major shock affecting society as a whole. Fourth, the open borders prime (highlighting the Chinese origin of the virus and its global spread through migration flows) did not have average effects on welfare preferences. However, this prime activated other-regarding considerations, which in turn reduced welfare state generosity among anti-immigrant respondents. This means that racialized and immigrationbased framings of the pandemic have the potential to polarize redistributive preferences indirectly, via immigration policy preferences.

We make three contributions. First, we speak to the literature on crises and social policy preferences by conducting a comprehensive test of different theoretical micro mechanisms. Rather than only testing whether crises matter, we focus on why they matter. From this perspective, socio-tropic theories predicting aggregate left-wing shifts in public opinion, and theories expecting wider and cross-cutting risks to boost welfare preferences (Rehm et al., 2012), are particularly well suited to make sense of our findings. By contrast, income-maximizing motivations and insurance against individual unemployment risk are not consistent with our results. Interestingly, while immigration attitudes have not systematically changed during the pandemic (Dennison et al., 2021), our analyses unveil subtle indirect effects on redistributive conflicts. Certain framings of the pandemic in public discourse can first polarize anti-immigrant preferences, and then depress pro-spending preferences among citizens hostile to immigration.

Second, we speak to an emerging literature focusing on the consequences of the Covid-19 crisis on liberal democratic institutions (Arceneaux et al., 2020; Amat et al., 2020; Bol et al., 2020). We experimentally disentangle different facets of the crisis (i.e. economic turmoil, health toll, risks of open borders) that are necessarily confounded in observational analyses. This strategy allows us to causally identify a substantial average left-wing turn in British public opinion that did not emerge in recent observational and comparative studies (Ares et al., 2021; Busemeyer, 2021). Consistently with Heap et al. (2021)'s experimental study on fiscal adjustments, we find exogenous depolarizing effects of the pan- 
demic that do not map well onto existing socio-economic cleavages. However, our treatment effects are linked to the short-term economic and health shock of the pandemic, and shaped preferences over spending rather than on how exactly to redistribute the burden of the Covid bill. Thus, contrary to Heap et al. (2021), our results do not necessarily suggest a lasting shift in favor of a new post-pandemic fiscal contract. Moreover, we fielded the same experiment in October 2020 in the US, and we could not replicate the same results obtained in Great Britain. We are thus necessarily cautious about the external validity of our findings beyond Britain, and the long-term redistributive effects of the pandemic once the economic and health crises are kept under control (Margalit, 2013).

Third, we systematically analyze both spending and taxing preferences, and go beyond generic preferences of state intervention in the economy. This allows us to distinguish between different policy priorities focused on consumption (i.e. unemployment protection) and investment (i.e. health policies) (Häusermann, 2018; Abou-Chadi and Wagner, 2019). Similarly, our outcomes allow us to disentangle agreeable forms of paying for the Covid bill, including increased levels of progressive income taxation and the introduction of a wealth tax. Our results indicate that the consensus on increased spending priorities is much higher than the consensus on who should pay for them. Only the health toll of the crisis (and not so much the economic one) has increased preferences for taxing higher incomes disproportionally more. This is consistent with the effect observed in the aftermath of the 2008 Global Financial Crisis (Limberg, 2020). However, despite the relative support for wealth-based taxes observed in recent research (Fisman et al., 2020), we do not observe any significant connection between the Covid-19 crisis and preferences over wealth taxation.

\section{Hypotheses}

This section presents five theoretical expectations on the basis of interrelated literatures on public preferences for social welfare. We focus on five separate dimensions of the pandemic, namely socio-tropic conditions, egocentric perceptions based on income-maximizing and insurance motivations, other-regarding considerations, and perceptions of government competence.

When analyzing the effects of macro-economic turbulence on political outcomes, the economic voting literature has canonically distinguished between socio-tropic and egocentric perspectives. In studies of 
vote choice, socio-tropic perceptions of the state of the economy as a whole tend to be highlighted as particularly powerful determinants of the fate of incumbents and challengers (Lewis-Beck and Stegmaier, 2000; Duch and Stevenson, 2008). When looking at social policy preferences, the impact of macroeconomic crises is more disputed. On the one hand, shocks can dampen support for redistribution (Durr, 1993; Stevenson, 2001), especially if they induce aggregate economic inequality (Kelly and Enns, 2010). On the other hand, however, economic contractions can also shift citizens to the left of the ideological spectrum and increase pro-welfare attitudes (Blekesaune, 2007; Naumann et al., 2016).

Wlezien and Soroka (2021) make sense of these competing findings by unpacking the temporal dynamics of economic trends and public preferences towards welfare. More specifically, they find that unemployment can produce counter-cyclical short-term effects in support for welfare (Erikson et al., 2002), which add to the pro-cyclical effects of economic growth increasing public demand for welfare over time. This means that both short-term economic shocks and longer trends of growth can be hypothesized to increase welfare preferences. This expectation applies especially well to the Covid-19 economic crisis. The peculiar combination between demand and supply-side shocks induced by the pandemic affected a wide range of occupations and socio-economic profiles across the labor market (Brinca et al., 2020), which could have a substantial aggregate effect on increased support for welfare policies:

Hypothesis 1 (H1) - socio-tropic hypothesis: Being primed on the economic crisis triggered by Covid-19 increases support for raising taxes and spending.

While socio-tropic considerations are typically shown to be influential, egocentric or pocketbook calculations are famously considered weaker in retrospective accountability models. However, recent research shows that, when plausibly linked to government policy interventions, variations in personal economic circumstances can also condition the fate of political incumbents (Tilley et al., 2018). Personal economic circumstances have been the main traditional focus of the literature on welfare policy preferences. A long tradition of studies has singled out material self-interest as the main driver of social policy preferences. In particular, income-maximizing motivations predict that one's position in the socio-economic spectrum should rationally drive spending and taxing preferences (Meltzer and Richard, 1981). 
Given their differential exposure to the economic shock and the financial burden of the recovery bill, we would expect individuals with higher (lower) levels of income to be less (more) likely to support higher levels of taxes and spending as a result of the Covid-19 economic crisis. Validating this hypothesis would suggest a high potential of the Covid-19 crisis to exacerbate polarization on redistributive conflicts along classical left-right divides in the years to come. Recent research on Covid-19 seems to suggest diverging findings on ideological polarization depending on the context. While Heap et al. (2021) find that exposure to the consequences of the crisis reduces ideological differences between Democrats and Republicans in the US, Ares et al. (2021) find that left-right divides exacerbated in a number of European countries. This suggests that ideology and partisan identities can have different effects across contexts, and perhaps encapsulate unobserved attitudinal or rational considerations of different sorts. We focus instead on the micro-mechanisms behind potential patterns of polarization driven by income calculations. This leads to our next hypothesis:

Hypothesis 2 (H2) - income maximizing hypothesis: Being primed on the economic crisis triggered by the pandemic exacerbates income effects on preferences for spending (i.e. the rich want less, and the poor want more).

The role of income-maximizing considerations, while theoretically influential, has been highly contested in the literature. Higher economic inequality does not correlate strongly with increased redistributive systems in aggregate-level analyses, and individual income levels do not systematically explain variation in support for social spending (Kenworthy and Pontusson, 2005; Rueda, 2017). This has generated an increasing interest in insurance and risk-based explanations for social policy preferences (Iversen and Soskice, 2001; Rehm, 2009). From this perspective, labor market risk is mostly orthogonal to income, and a systematic predictor of increased social policy preferences in anticipation of prospective economic shocks.

Margalit (2013)'s analysis confirmed the role of labor market shocks in the context of a crisis like the 2008 global financial meltdown. The personal experience of economic hardship, especially in terms of job loss, had a substantial effect on increasing support for welfare spending. It is also true, however, that massive and long-term changes in policy preferences as a result of economic shocks are relatively 
rare (Margalit, 2019). These contributions indicate that the personal experience of an economic shock can have a sizeable, even if transient, effect on citizens' social policy preferences. From this perspective, we would expect that the impact of the Covid-19 crisis increasing preferences for taxing and spending is amplified among those with high labor market risks. Precisely because the Covid-19 crisis has affected occupational sectors across the socioeconomic spectrum, risk-based theories emerge as a reasonable paradigm to predict the effect of the crisis in the short-term. This leads to our next hypothesis:

Hypothesis 3 (H3) - economic risk hypothesis: Being primed on the economic crisis triggered by Covid-19 increases preferences for taxes and spending via unemployment risk (H3a), and among those with high unemployment risk (H3b).

Theories focused on identity considerations have emerged as an influential strand of the literature on preferences for redistribution (Alesina and Glaeser, 2004; Lupu and Pontusson, 2011), especially given the limitations of models exclusively based on rational self-interest. This has led to the influential distinction between self-regarding and other-regarding preferences (Cavaille and Trump, 2015). While self-regarding considerations focus on taking resources from a given group (generally the rich), the latter is focused on giving resources to another group (generally the poor). When the utility of redistribution is a function of other-regarding considerations, the ethnic identity and cultural similarity of welfare beneficiaries become a powerful determinant of increased social policy preferences among local populations.

Other-regarding considerations are an important framework to consider the potential impact of Covid19 on social policy preferences. The pandemic has a genuinely global component. Earlier demographic analyses suggest that the virus spread through specific international travelling routes (Yucesahin and Sirkeci, 2020). Debates on the appropriateness of closing borders and actual restrictions on air travel could have reinforced wariness against open borders, and fear of foreigners transmitting the virus. As regards minority attitudes, there is evidence of the 'racialization' of the virus by certain political and media narratives (i.e. 'Chinese virus') affecting attitudes towards Asian minorities in the early stages of the pandemic (Reny and Barreto, 2020). It is thus reasonable to expect that the Covid-19 crisis might have reinforced constructions of ethnic otherness or increased hostility against certain kinds of migrants and minorities, and that this in turn has decreased preferences for taxes and spending, leading to our next 
hypothesis.

Hypothesis 4 (H4) - out-group hostility hypothesis: Being primed on immigration pressure decreases support for taxes and spending, directly (H4a) and via immigration policy preferences (H4b).

Finally, the Covid-19 pandemic has put political performance on the spotlight. Governments across the globe have adopted a myriad of policy interventions to contain the virus, from lockdowns and school closures to social distancing and other restrictions on mobility and certain types of civil liberties (Hale et al., 2021). The death and health toll of the pandemic, however, has been unprecedented worldwide, and particularly high in our cases of study. The government management of the pandemic in both the US and the UK was publicly questioned, especially given the dramatic rates of hospitalizations and deaths due to Covid-19.

Theories on quality of government and political performance predict that, in case of governmental distrust and political mismanagement, the public decrease their preferences for public welfare provision (Peyton, 2020). Political trust and perceptions of political competence have been highlighted as important moderators of support for additional spending on health care in Germany (Busemeyer, 2021) after the pandemic. We would therefore expect that, when primed on the high death tolls of the pandemic and the contested success of governments and health systems at containing the virus, citizens would support taxes and public spending less, and perhaps opt for private and alternative forms of insurance. This leads to our last hypothesis.

Hypothesis 5 (H5) - competence hypothesis: Being primed on government mismanagement of the pandemic decreases support for taxes and spending.

\section{Research design}

To test our hypotheses, we use a survey experiment priming respondents on different aspects of the Covid-19 crisis. Survey experiments prime latent attitudinal and behavioral traits and are a powerful tool for causal inference (Krupnikov and Findley, 2018). This approach is particularly valuable when studying attitudes that are likely to be confounded by underlying partisan and ideological considerations. 
The scope of our findings is inevitably limited by the conditions created by the experiment and the context in which they were received. Our main objective is to leverage the multifaceted character of the Covid-19 shock in order to scrutinize the internal validity of alternative mechanisms that are ambiguously tested in the literature on crises and social policy preferences. We thus aim at estimating the causal effect of scenarios that are credibly connected with the Covid-19 crisis, rather than adjudicating which of those scenarios or narratives prevailed in real life. While external validity is not our primary objective, however, we did embed our experiment in a representative sample of the British population. Data collection took place between 3-15 February 2021, in the lead-up to the 2021 government budget announcement on 3 March 2021, at a time in which the economy and Covid-19 were highly salient issues in the public. ${ }^{1}$ We registered the data collection and data analysis of this study at the OSF on 23 October 2020, before any data collection commenced. ${ }^{2}$

Participants were recruited from an online access panel administered by the company Deltapoll. No direct financial incentives were given. However, respondents got some virtual tokens, which they can ultimately exchange for some money or vouchers. The survey includes 880 individuals for whom we have complete responses on all relevant variables. The sample is representative of the population living in Great Britain (England, Scotland and Wales). Table A.1 in the Appendix tabulates key demographic characteristics of our sample, and shows a remarkably high correspondence with a high-quality sample from the 2019 British Election Study face-to-face survey, which is based on a probability sample. ${ }^{3}$

With 216 to 227 respondents in each treatment arm, our analysis is well powered according to standard calculations. As it is conventional to do, we assume $95 \%$ level of statistical significance and $80 \%$ statistical power. We then calculate the standardized difference that we expect to find between our control and each of our treatment groups: difference between the means / standard deviation of our outcome in the population (Jones et al., 2003). We assumed 5\% difference in the means of our outcomes between our treatment and control group (for instance, a difference between 5 in the control and 5.5 in the treatment

\footnotetext{
${ }^{1}$ https://www.bbc.co.uk/news/business-55765868 (accessed 20/05/2021).

2 The Pre-Analysis Plan is available here: https://osf.io/sgpd2/?view_only= d0771a0aec4346a58c58d26a75ddbdec

${ }^{3}$ Our sample has significantly over-sampled respondents with a degree and slightly over-sampled respondents who own their home without a mortgage. In terms of age, gender, ethnicity, the sample is however very close to the expected population distribution.
} 
group, on a 10-point continuous scale), and a standard deviation of 1.5 in our outcome. According to these assumptions, we would need around 176 individuals per treatment group for a well-powered analysis. After data collection and analysis, we observed that our assumptions on effect magnitudes were quite accurate (as indicated in Figure 2 below, our main effects range from 5\% to 9\%) and the standard deviation of our spending preferences outcomes was 2.8 .

\subsection{Experimental design}

After consenting to participate in our study, respondents were first asked a few pre-treatment variables: gender, age, education, partisanship, and region of residence. Then, they were randomly assigned to the control group or one of our three treatment groups. Outcome variables were directly asked after the exposure to the treatments, followed by some variables needed to test our hypotheses above. The survey finished with some additional demographic questions on income, domicile, ethnicity and religiosity. ${ }^{4}$

We randomly assigned three treatment conditions and one control group to our sample. Each experimental condition makes up $25 \%$ of the sample. As we show in Table A.2 in the Appendix, the randomization of our treatment was largely successful, based on key demographics: gender, age, education, political interest, partisanship, working status, housing, urban/rural residence, ethnicity, and religiosity. Estimating a multi-nominal logistic regression of treatment allocation (reference category: control group), we find only significant differences in terms of housing and to a weaker extent for domicile. To deal with these small imbalances between the treatment groups and the control group, observed demographic characteristics are included in the regression models, presented below as control variables.

\subsection{Variables}

\subsubsection{Experimental treatments}

Our main independent variable is the random assignment to the control group or one of our three treatment groups. This variable has four values: 1) "control group"; 2) “economic debacle"; 3) "open bor-

\footnotetext{
${ }^{4}$ The ethical considerations of this study have been anonymously peer-reviewed and officially approved (on 9 Oct 2020) by the Ethics Committee of the XXXX at the University of XXXX following standard ethical review procedures. Reference number: XXXX. [information removed for author anonymity.]
} 
ders" and 4) "health crisis". The control group was not exposed to any vignette or mentioning of Covid19. All treatment conditions report factual statistics from official sources or academic studies, and the sources were provided in the vignettes. The wording of the vignettes for each treatment is the following:

ECONOMIC DEBACLE - T1: "According to official data from the UK government, the economy has declined dramatically over the last few months. GDP decreased by $20.4 \% 5$ following the start of the coronavirus outbreak, which is ten times higher than after the financial crisis in $2008 .{ }^{6}$ The unemployment rate has further increased by $1 \%$ in 2020 compared to $2019 .{ }^{7}$,

OPEN BORDERS - T2: "Recent academic studies have linked the spread of coronavirus to migration and specific travelling routes originating in Central China and spreading across the world. Based on data from the Office for National Statistics, immigration to the United Kingdom has doubled since $1991,{ }^{8}$ reaching unprecedented levels. According to recent estimates, the UK foreign-born population has reached a record 9.5 million. ${ }^{9} "$

HEALTH CRISIS - T3: “According to data from John Hopkins University, the death toll in the UK due to the coronavirus outbreak is among the highest in the world, well surpassing 90,000 deaths. ${ }^{10}$ The Westminster government has been under intense scrutiny recently, accused of being slow to coordinate a national response and sending unclear messages."

Given previous evidence on the 'racialization' of the virus during the Covid-19 pandemic (Reny and Barreto, 2020) and the intensity of immigration debates in our contexts of interest, our open borders treatment intentionally primes the foreign origin of the virus and the risks of global transmission. We

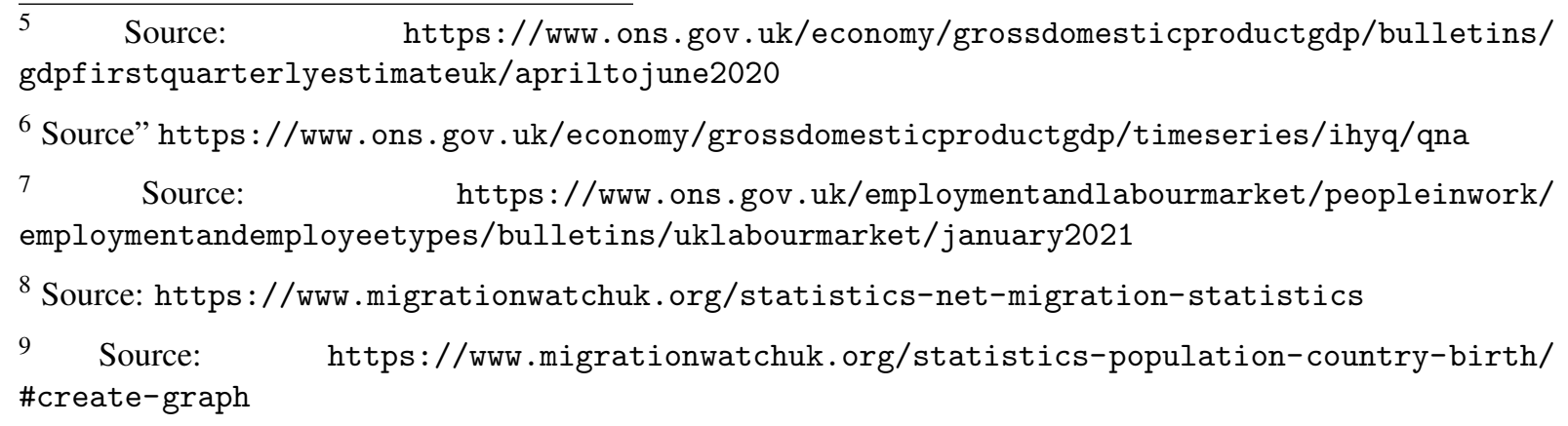

${ }^{10}$ Source: https://coronavirus.jhu.edu/map.html 
have no obvious reasons to suspect that the China and immigration primes are cancelling each other out or adding unintended stimuli beyond the out-group considerations that we intend to prime. We rather see them as coherent references highlighting the risks of globalization, and credibly in line with part of the narrative existing in the public debate.

Similarly, the health crisis treatment adds a scientific source to deal with a controversial issue prone to misinformation, and to avoid deception. It could be argued that this elicited anti-elite feelings or distrust toward scientific authorities among certain types of respondents. Once again, we do not see the co-existence of primes eliciting distrust towards the management of the pandemic (political, scientific or otherwise) as contradictory with the spirit of our fifth hypothesis. This treatment is designed to highlight controversies over the potential mismanagement of the health crisis, and to subsequently reduce public willingness to increase taxes and spending.

Immediately after each treatment, respondents assigned to that particular vignette were asked about a related opinion on subjective unemployment risk, immigration policy, or political performance respectively.

\subsubsection{Outcome: Welfare attitudes}

To measure our outcomes we rely on four measures. Firstly, we focus on spending, distinguish between spending on unemployment benefits and health. In the second set of outcome variables, we ask respondents more directly about their preferences for progressive taxation as well as taxing on wealth. More specifically, the question wording for each outcome variable is as follows:

- Spending unemployment: "Imagine that the government had to choose between increasing taxes and spending more on unemployment benefits, or decreasing taxes and spending less on unemployment benefits, which should they do?" 0 - Increase taxes and spend more on unemployment benefits; 10 - Cut taxes and spend less on unemployment benefits.

- Spending health: "And what about public health? If the government had to choose between increasing taxes and spending more on public health, or decreasing taxes and spending less on public health, which should they do?" 0 - Increase taxes and spend more on public health; 10 - 
Cut taxes and spend less on public health.

- Tax progressivity: "Taking everything into account do you think people with high incomes should generally pay a larger share of their income in taxes than people with low incomes, the same share, or a smaller share?" 1 - A much smaller share; 5 - A much larger share.

- Wealth tax: "Instead of income, now think about wealth. Imagine a tax on wealth such as savings, investments, stocks, properties and other assets. People with a current total wealth of over $£ 750 \mathrm{k}$ would be taxed a percentage of the total wealth of their current assets. They would only be taxed above that $£ 750 \mathrm{k}$ limit and this would exclude any personal pension savings and their main home. Would you support the introduction of a wealth tax such as this?” 1 - Strongly oppose; 5 - Strongly support.

To allow comparability of the variables, each variable was recoded to range from 0 (no support) to 1 (most support). To compare the distribution of support for the various measures of welfare attitudes, Figure 1 plots the density function for each of the four variables, as well as the mean (red, dotted line). As the graphs show, the variables are normally distributed, with support for more spending on unemployment being the lowest.

\subsubsection{Moderating and mediating variables}

Based on our pre-registered hypotheses and analytical strategy, we expect different variables to moderate or mediate the effect of the pandemic on redistribution preferences. Following $\mathrm{H} 2$ we expect income to exacerbate the impact of the pandemic on support for welfare and taxation. To measure income, respondents were asked to state their combined, pre-tax annual household income, ranging from less than $£ 7,000$ (1) to $£ 83,001$ and above (13). While income is an important measure of personal economic circumstances, it inevitably misses other important aspects like property of assets (Nadeau et al., 2010; Stubager et al., 2013; Nadeau et al., 2019) and class or occupation (Evans and Tilley, 2017).

Our third hypothesis focuses on the moderating and mediating impact of individuals' economic risk, which is measured using subjective unemployment risk. We use a four-categorical scale asking respondents "how likely do you think it is, if at all, that during the next 12 months you will be unemployed 
Figure 1: Descriptive distribution of outcome variables
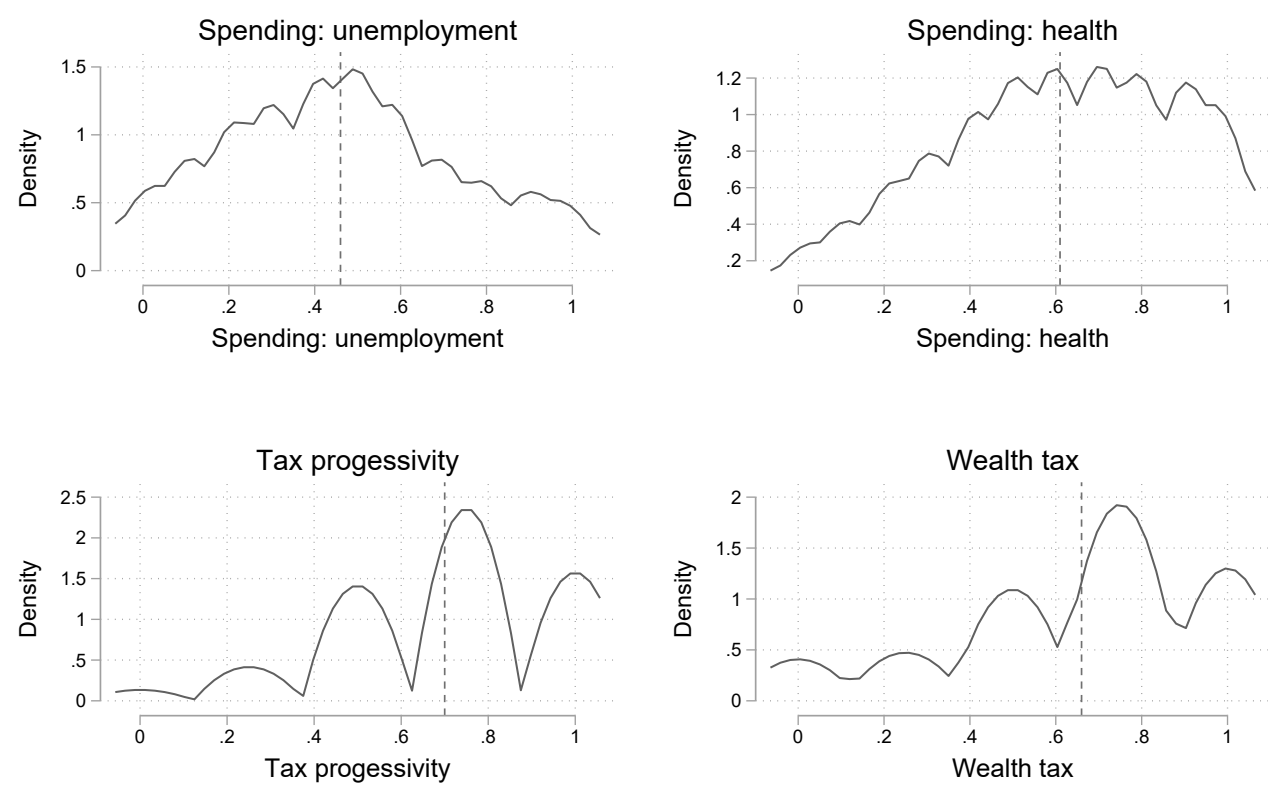

Note: Red, dotted line indicates average position for each variable.

and looking for work for at least four consecutive weeks?", ranging from 1 "very likely" to 4 "not at all likely". Respondents who do not seek work are coded as missing.

Next, we look at the conditioning and mediating effect of immigration preferences (H4), asking respondents "How restrictive, if at all, do you think immigration policy in the United kingdom should be?". Responses range from not at all restrictive (1) to extremely restrictive (5).

It is important to note that subjective economic risk and immigration policy preferences are posttreatment. The hypotheses involving those variables expect mediating effects, implying that they are shaped by the treatment and channel its effect on the outcome.

\subsubsection{Additional control variables}

As mentioned above, our main models will control for housing situation and type of domicile, which showed significant associations with our treatment assignments. As also outlined in our pre-registration 
plan, the models below control for key demographic variables allowing us to compare effect sizes and potentially increase the precision of our estimates:

- Gender: Female (48.4\%)

- Age: average $=47.9$

- Education: Degree (48.0\%)

- Employment: Working (59.1\%)

- Ethnicity: White (88.3\%)

- Political interest: average $=8.1$ (on 0 to 10 scale)

- Religion: Religious (48.6\%)

- Housing: Own - no mortgage (41.1\%), own - with mortgage (27.2\%), renting (31.7\%)

- Domicile: Urban (20.9\%), Suburban (40.4\%), small city or sizable town (7.7\%), Rural (30.9\%).

- Partisanship: None (12.7\%), Conservative (35.1\%), Labour (33.6\%), Other (18.5\%)

\section{Results}

\subsection{Main effects of Covid primes (H1+H4a+H5)}

We first look at the direct impact of our three Covid primes on welfare attitudes. The results are reported in Figure 2, which plots the regression coefficients and their $95 \%$ confidence intervals of the impact of the three Covid primes on the four outcome variables. The results are based on linear regression controlling for housing and domicile, which are not fully balanced between treatment groups. Appendix A.3 further reports the full set of results, which additionally include all pre-treatment controls, and show identical substantive results.

As Figure 2 demonstrates, priming people on the economic debacle of the pandemic has the expected impact on spending preferences (H1). Those primed on the economic impact of the pandemic have a 5 percentage point increase in support for unemployment spending compared to the control group. The 
Figure 2: Regression coefficient and 95\% confidence intervals of Covid treatments on welfare attitudes

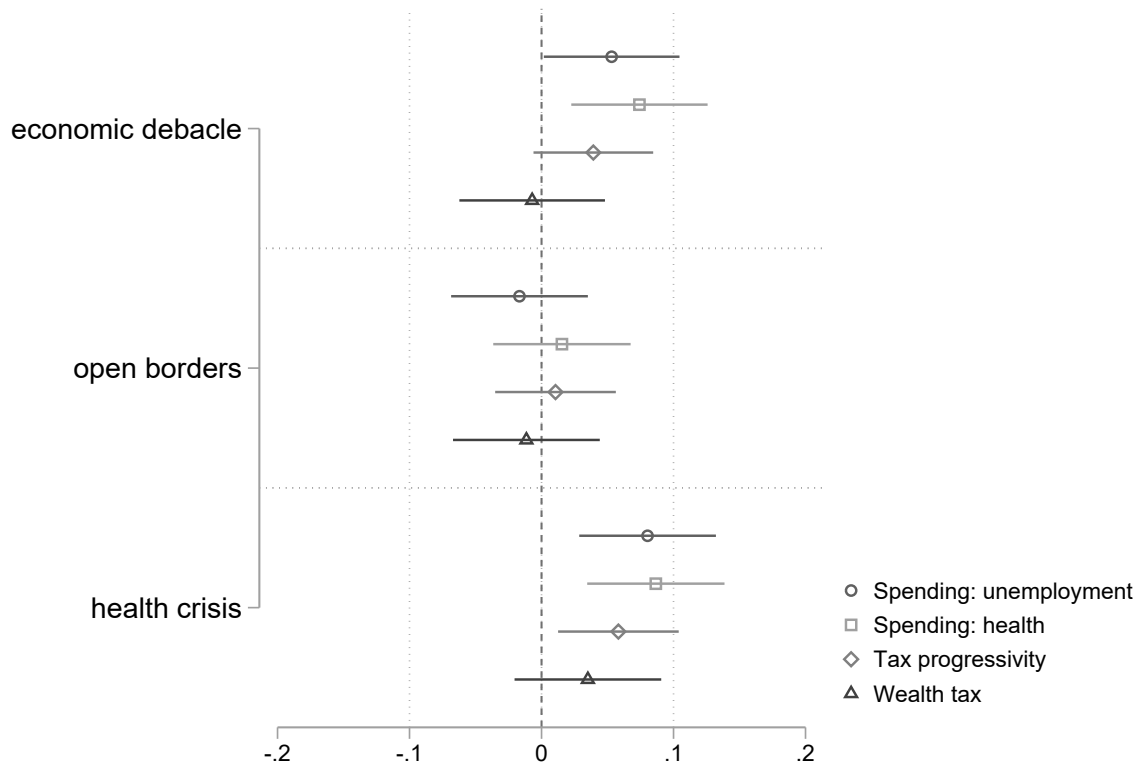

Note: The results are based on linear regressions, controlling for housing and domicile. All outcome variables were standardized to range from 0 to 1 . The regression coefficients and standard errors are reported in Table A.3 in the Appendix.

treatment further increases support for health spending by about 7 percentage points compared to the control group. The effects are significant at the 5\% level and robust to the inclusion of further pretreatment controls. The economic treatment drives support for increased tax progressivity only at the $10 \%$ level (increase of about 4 percentage points), but has no effect on support for a wealth tax.

Figure 2 further shows a significant impact of the health crisis prime, which increases support for unemployment ( 8 percentage points) and health spending (9 percentage points), as well as increased support for tax progressivity (6 percentage points). Interestingly, H5 expected that the incapacity to control the pandemic would lead to reduced levels of trust in governmental competence, which are known to correlate with reduced welfare state generosity. However, the results point towards the opposite direction. The public largely exonerated the government from the comparatively worse death toll of the pandemic in Britain, focused on the abysmal health toll, and increased expenditure and taxation demands for a more resilient social insurance system.

Lastly, the results do not indicate that priming people on open borders and the connection to the 
Figure 3: Marginal effects of economic prime and $95 \%$ confidence intervals on welfare attitudes by income
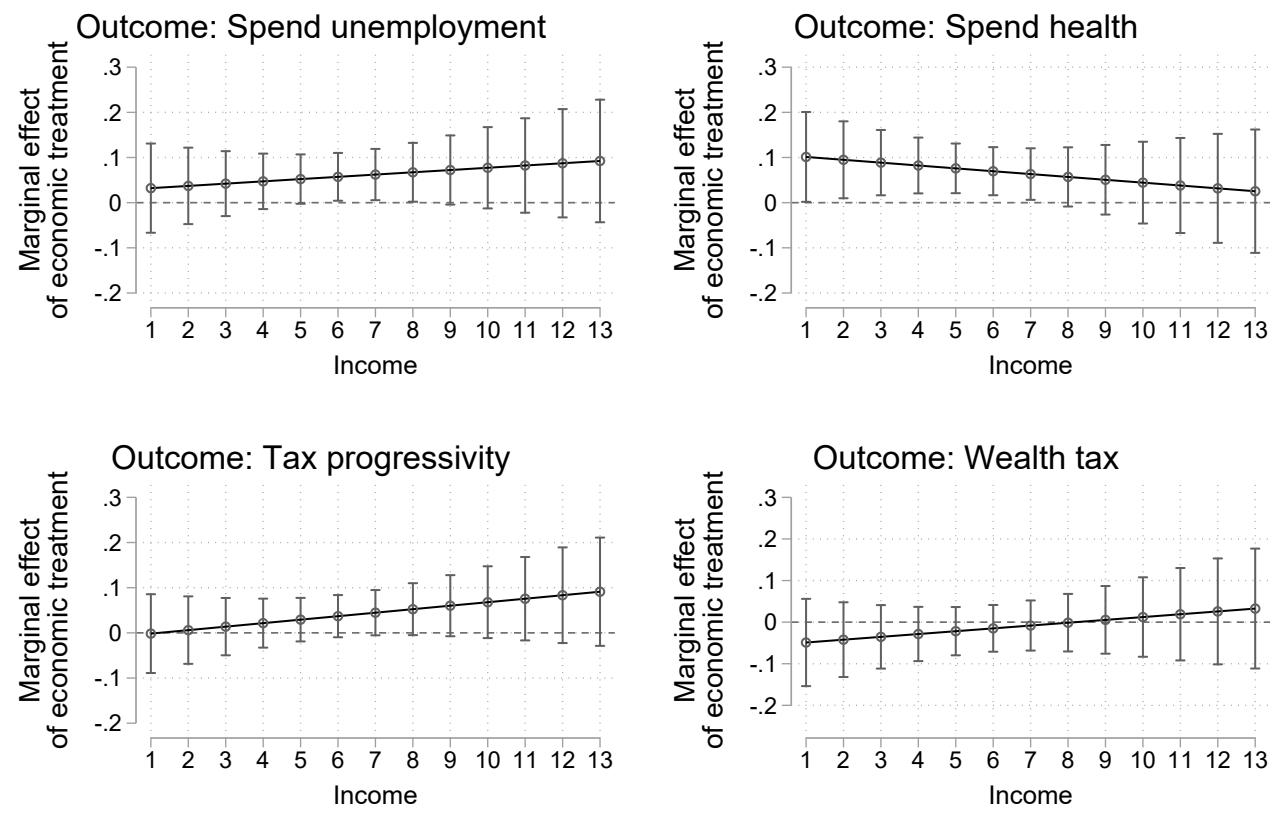

Note: The results are based on linear regressions, controlling for housing and domicile. All outcome variables were standardized to range from 0 to 1 .

pandemic has any direct impact on welfare preferences. We therefore reject $\mathrm{H} 4 \mathrm{a}$, which predicted a direct impact of the immigration prime.

\subsection{The economic debacle and income (H2)}

In the next step, we investigate the impact of the economic debacle prime in more detail by looking at heterogeneous effects by income. Figure 3 plots the marginal effects of the economic treatment - compared to the control group - on welfare attitudes by income, which is measured from (1) less than $£ 7,000$ to (13) more than $£ 83,000$ pre-tax household income. Based on the income maximizing hypothesis (H2) we expect that the pandemic will exacerbate income effects on preferences for spending, which would imply that the rich want less, and the poor want more.

Based on the findings presented in Figure 3, we observe that the impact of the economic prime is only significant and positive among respondents with an annual household income of up to $£ 48,000$, 
while we do no see any impact of the economic debacle on increased support for health spending among richer respondents. However, the slope of this interaction term is non-significant. We cannot thus rule out the possibility that the economic treatment effects are the same across the whole income continuum. The interactions between our treatment of interest and income predicting all other outcomes are clearly insignificant, broadly disconfirming $\mathrm{H} 2$.

\subsection{The economic debacle and unemployment risk (H3)}

In the next step, we investigate the impact of the economic debacle prime in more detail by looking at economic effects via (H3a) and by (H3b) unemployment risk. Table 1 reports several mediation models following the method developed by Imai et al. (2011). Using linear regression analysis, the first column tests the impact of the economic treatment on subjective unemployment risk. Columns 2-5 in Table 1 test the impact of subjective economic risk on our outcomes of interest: unemployment benefits, public health, income tax progressivity, and wealth tax. Columns 2-5 also report the Average Causal Mediation Effect (ACME), capturing the magnitude and significance of the treatment effect via unemployment risk. A meaningful indirect effect would imply significant effects of the treatment on the mediator, of the mediator on the outcome, and of the ACME.

Table 1 disconfirms H3a. Column 1 shows that the economic treatment did not significantly increase perceptions of individual unemployment risk. There might be a number of reasons for that, including the heavy investment of the UK government on a wide-reaching job protection scheme from early on in the pandemic (furlough scheme). ${ }^{11}$ More importantly, the ACMEs are all negligible in magnitude and statistically insignificant, indicating that the effects of the economic prime were not channeled through perceptions of unemployment risk.

Figure 4 tests $\mathrm{H} 3 \mathrm{~b}$, which predicted heterogeneous treatment effects across levels of unemployment risk. More specifically, we expected that the pandemic will lead to more demand for social spending and more progressive taxes among those more at risk of unemployment. Figure 4 plots the marginal effects of the economic treatment - compared to the control group - on welfare attitudes from (1) no risk to (4) very likely to become unemployed. Our expectation is only partially confirmed for health spending

11 https : //www.bbc.co.uk/news/explainers-52135342 (25/09/2021) 


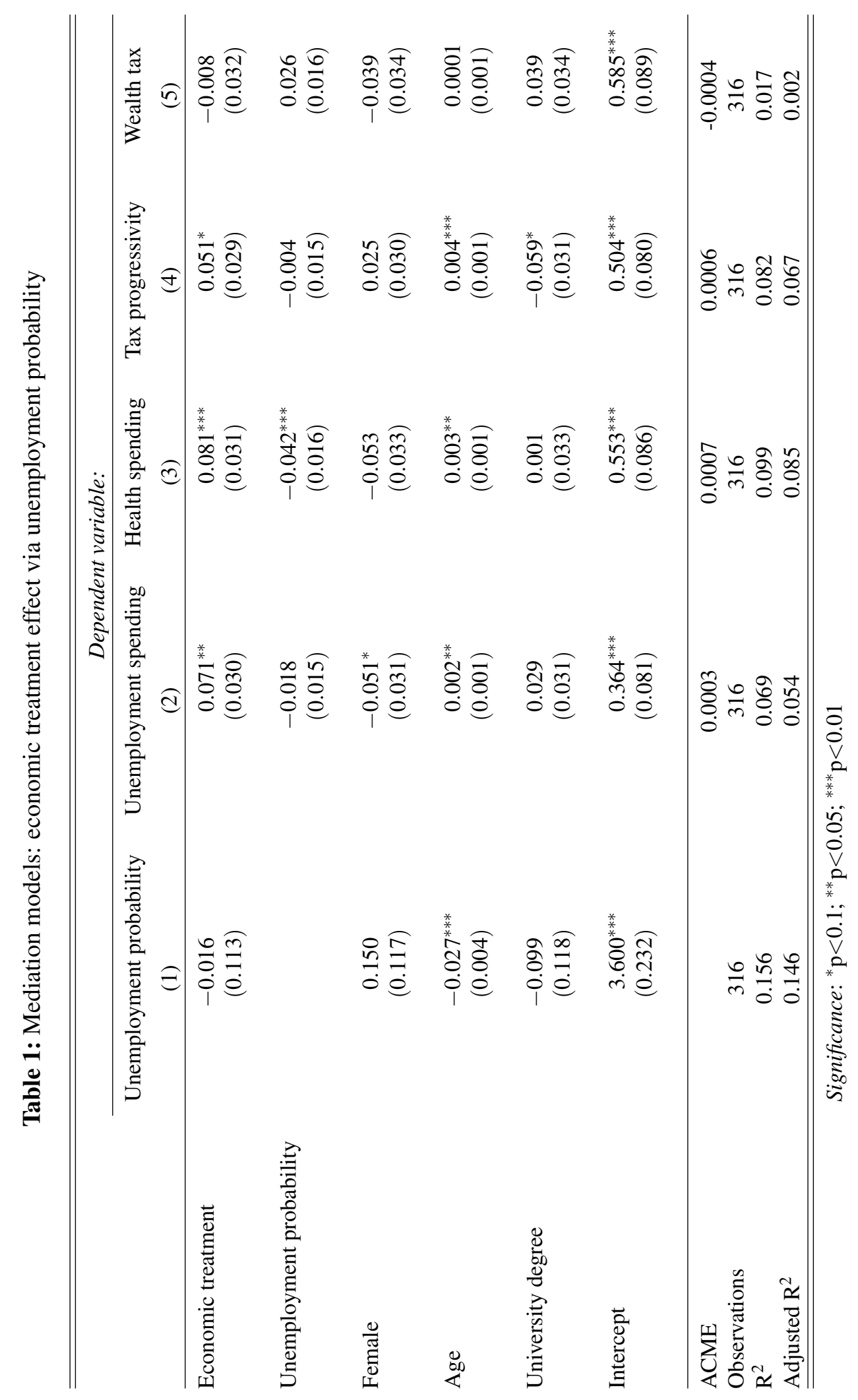


Figure 4: Marginal effects of economic prime and $95 \%$ confidence intervals on welfare attitudes by unemployment risk
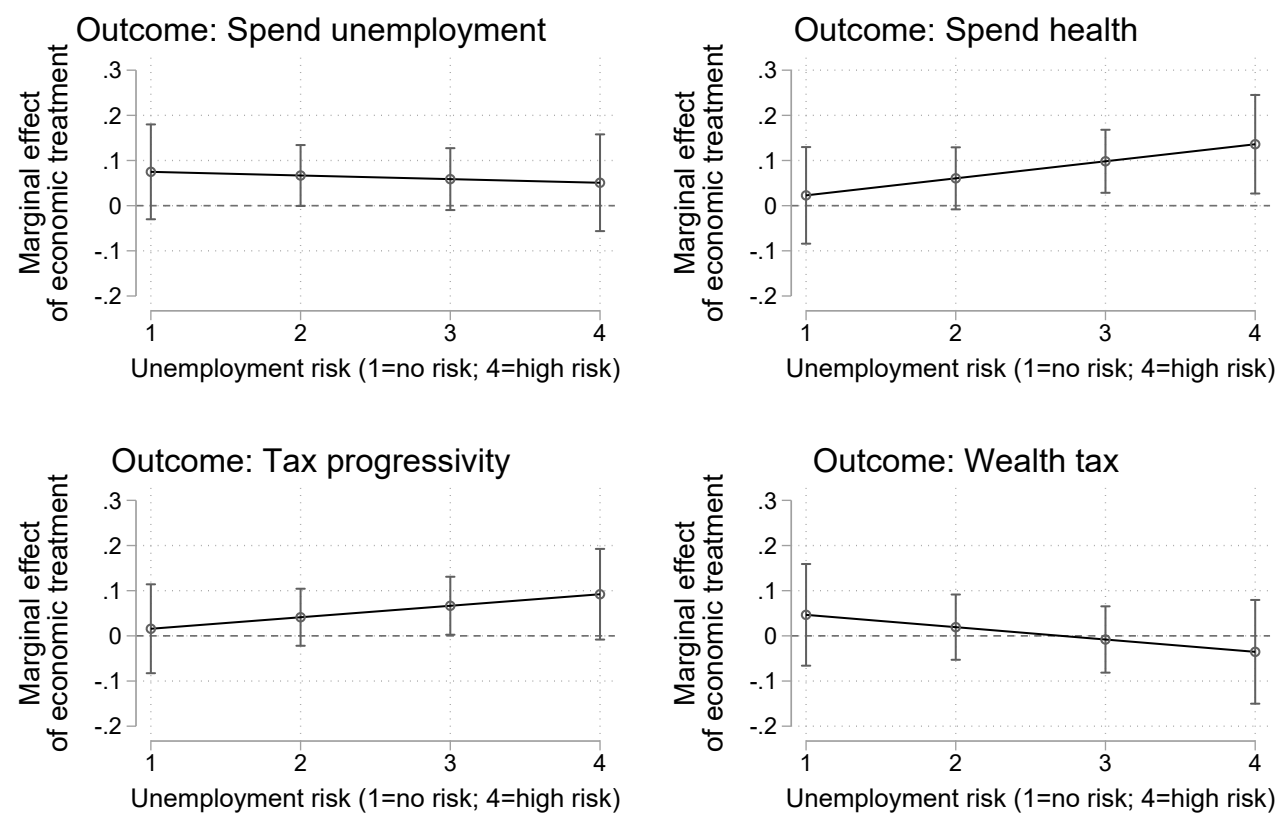

Note: The results are based on linear regressions, controlling for housing and domicile. All outcome variables were standardized to range from 0 to 1.

support. The impact of the economic prime is positive and different from 0 among respondents that are at risk of loosing their employment. However, the slope of this interaction term is insignificant, suggesting that treatment effects could be the same among respondents with low and high risk. Moreover, according to insurance models of redistribution preferences, it is not obvious why respondents at high risk in the labor market would increase their support for health programs and not for unemployment benefits. The other marginal effects reported in Figure 4 show insignificant results, broadly disconfirming insurance and risk-based theories as likely mechanisms for the effect of the pandemic.

\subsection{The economic debacle and anti-immigration preferences $(\mathrm{H} 4)$}

Next we investigate the impact of the open borders prime in more detail by looking at its indirect effects via anti-immigration policy preferences (H4b). While Figure 2 above disconfirmed direct effects of our open borders prime on spending and taxing preferences (H4a), Table 2 clearly confirms H4b and suggests 
that the effects of immigration considerations are more indirect and subtle.

The first column confirms that priming on the global origin and spread of the virus significantly and strongly increased anti-immigrant policy preferences. In turn, and consistently with identity-based theories of redistribution, columns 2 and 3 show that anti-immigrant preferences are associated with lower support for unemployment and health spending. The ACMEs in those models are strong and highly significant (1-5\% level), providing further evidence in favor of the conclusion that the pandemic could shape spending preferences via other-regarding considerations. Immigration seemed to affect spending preferences on unemployment and health, but not wealth and income tax progressivity.

Even if we did not pre-register the following analyses, given the results in Table 2, we decided to explore further the role of immigration preferences. Figure 5 plots the marginal effects of the open borders treatment - compared to the control group - on welfare attitudes by anti-immigration preferences, which is measured from (1) pro immigration to (5) anti-immigration. The results confirm that the pandemic polarized spending preferences along the identity continuum: the impact of the borders prime is highly significant (positive) for respondents that are pro-immigration (+14 percentage points), while the prime strongly decreases support for unemployment spending for those against immigration (-9 percentage points). A similar pattern, even if slightly weaker, is also found for health spending. Once again, immigration considerations did not seem to shape views on who and how much to tax, but only on how much to spend.

Taken altogether, the results in Table 2 and Figures 2 and 5 suggest that framings of the pandemic focused on the global origin and spread of the virus did not affect welfare preferences on average, but shaped those preferences through, and polarized them along, immigration considerations.

\subsection{External validity}

The emerging literature on Covid and the welfare state is providing a number of important findings that seem to be context-specific. Observational research has found negligible effects in countries like Germany, Sweden, and Spain. Those effects, however, could have polarized left-right divides (Ares et al., 2021) and been moderated by perceptions of political competence and trust (Busemeyer, 2021). 


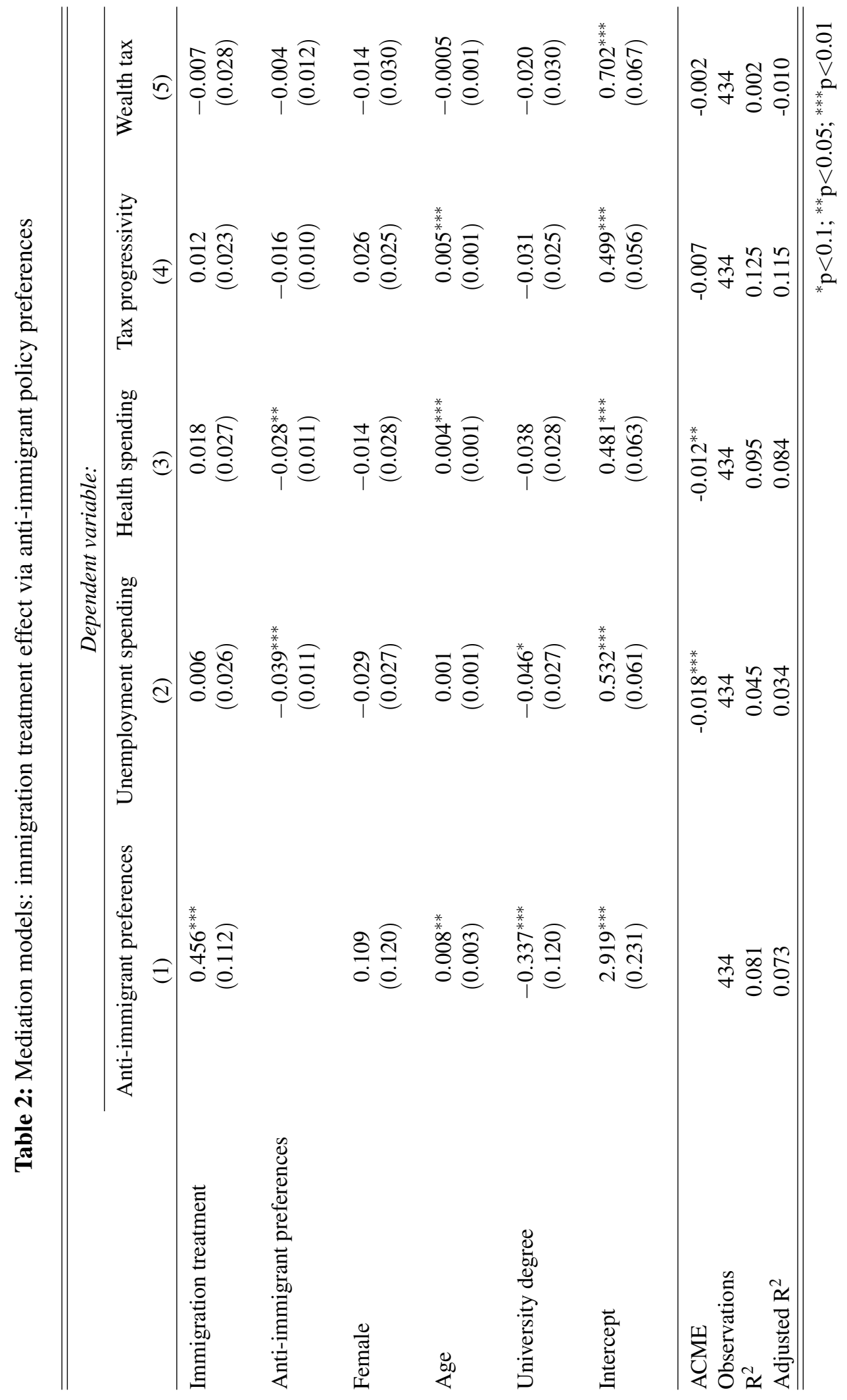


Figure 5: Marginal effects of open borders prime and 95\% confidence intervals on welfare attitudes by anti-immigration preferences
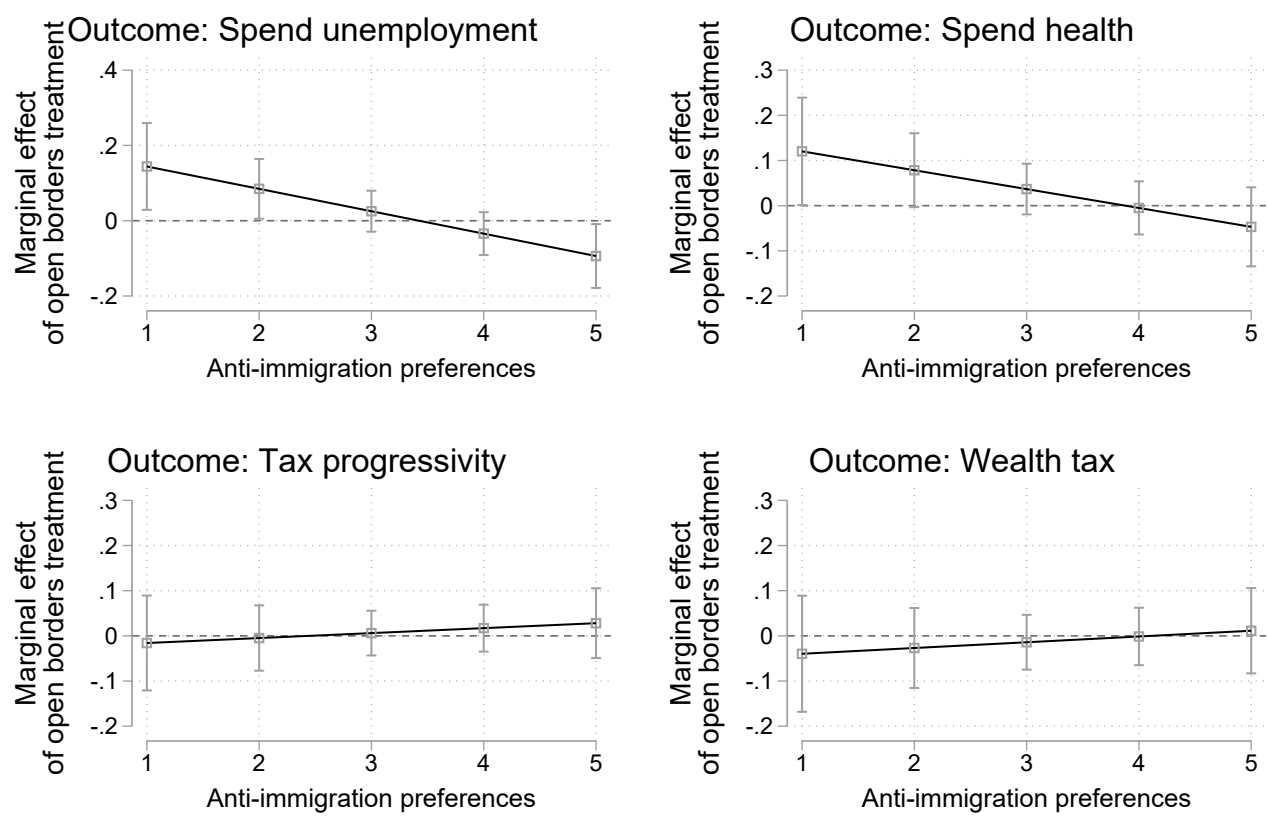

Note: The results are based on linear regressions, controlling for housing and domicile. All outcome variables were standardized to range from 0 to 1 .

By contrast, like our findings, experimental research by Heap et al. (2021) reveal more substantial average effects of the pandemic on public attitudes toward welfare.

Even if our focus here is on internal validity, we replicated our experiment in the US to get a sense of how generalizable our findings could be. We replicated the very same research design that we used in Britain with the same survey company. This should allow us to rule out research design effects and focus on differences across geographical and institutional settings. Data collection took place between October 21-29, 2020, and yielded a sample of 1,200 individuals representative of the US population.

Our findings in Britain failed to replicate in the US. Figures A.2, A.3 and A.4 in the Appendix report our main treatment effects, heterogeneous effects across levels of income, and across levels of unemployment risk respectively. Only the interaction between our economic treatment and income predicting support for unemployment benefits would appear to be consistent with income-maximizing motivations. Despite the intuitive sign of this result, however, the slope and marginal effects of the interaction are 
statistically insignificant.

Tables A.4 and A.5 test our hypothesized indirect effects of our economic and immigration treatments via unemployment risk and anti-immigrant attitudes respectively. Contrary to expectations, our treatments were not able to shape the distribution of our attitudinal mediators, and our estimated Average Causal Mediation Effects were always far from reaching statistical significance.

Given the well-known effects of partisanship in attitude formation in the US, we explored whether partisan identification could be moderating the effects of our treatments as a post-hoc hypothesis. Table A.6 in the Appendix provides suggestive evidence in this regard. Some of our treatments (especially on the economic and health crises) had significantly weaker effects among Republicans than among Democrats. Our design and power calculations did not contemplate a nuanced analysis of heterogeneous treatment effects across more precise partisan categories. However, the effect of ideological priors and institutional settings emerges as an important avenue in future research on crises and welfare attitudes.

Rather than a sign of the invalidity of our results in Britain, we interpret the US findings as a useful confirmation that the effect of the pandemic on welfare preferences has not been universal. The cumulative effort in the emerging literature on Covid-19 and welfare preferences seems to reveal a context-specific pattern whereby the effects of crises might depend on institutional settings, individual predispositions, and perhaps the timing of data collection.

\section{Discussion and conclusion}

The Covid-19 pandemic created a left-wing turn among the British public. Our results are consistent with previous research identifying short-term pro-spending turns in the context of major economic crises (Blekesaune, 2007; Margalit, 2013; Naumann et al., 2016; Limberg, 2020; Heap et al., 2021; Wlezien and Soroka, 2021).

Our survey experimental methodology allowed us to disentangle the mechanisms and causal effect of different aspects of the pandemic, and contribute to the literature on whether and why crises shape public preferences (Margalit, 2019). Our findings show that the economic, and especially the health toll of the pandemic had a substantial average impact on increased preferences for spending on public health and 
unemployment benefits. The effects of the pandemic on the redistribution of the tax burden have been weaker, however: only the health dimension of the crisis marginally increased preferences for income tax progressivity, and none of our primes significantly increased demands for taxing wealth to pay for the Covid bill. In terms of mechanisms, canonical redistribution theories based on self-interest fared poorly to explain our results. The pandemic did not increase spending preferences via self-interested calculations focused on income-maximization or individual unemployment risk. The effect has been rather socio-tropic - a reaction to a generalized cross-cutting risk affecting society as a whole (Duch and Stevenson, 2008). The public did not seem to distinguish between consumption or investment type of social policies on this occasion: the pandemic increased support for unemployment programs and public health systems, regardless of the actual exposure to those benefits.

A key finding of our British experiment concerned the role of immigration considerations. Public frames of the pandemic focused on the Chinese origin of the virus and its spread via global migration routes did not have average direct effects on our outcomes. However, our analyses of mediated and heterogeneous treatment effects revealed more subtle patterns. According to our experiment, the open borders prime significantly increased anti-immigrant policy preferences, which subsequently decreased pro-spending preferences. The treatment effects conditional on immigration preferences confirmed that, while immigration considerations did not have average effects, they did polarize redistribution outcomes. Pro(anti)-immigration respondents were substantially more in favor (against) spending preferences when exposed to the open borders prime.

This finding speaks to other polarization effects of the pandemic along general left-right pre-dispositions found in recent research (Ares et al., 2021). Immigration considerations, however, had low saliency during the pandemic, including in the UK (Dennison et al., 2021). This means that, while our experiment clearly documents the strong potential of immigration-based framings of the pandemic to shape welfare preferences, those framings should be prominent in public discourses for us to observe an effect in the real world, beyond our experimental setup.

What are the implications of our findings for longer-term redistributive conflicts and the sustainability of the welfare state in a post-pandemic world? Our design does not allow us to explicitly track long-term effects. However, our focus on experimentally disentangling different facets of the crisis revealed that 
the effects are socio-tropic, not strictly self-interested, and very much linked to the major economic and health toll caused by the pandemic. It is reasonable to speculate that the effects will be short-term as they have been in previous crises (Margalit, 2013), especially if the vaccine rollout is successful at containing the virus and when the economy gets back on track.

The lack of replicability of our experiment in the US context, the absence of average effects of the pandemic in observational effects conducted in other countries (Ares et al., 2021; Busemeyer, 2021), and the weaker effect of the pandemic on some taxing preferences push us to be cautious about the emergence of a new, enduring, and post-pandemic fiscal New Deal. From a theoretical perspective, however, the Covid-19 shock provided a genuine opportunity to unpack in which way and why crises can shape welfare preferences. 


\section{References}

Abou-Chadi, Tarik and Markus Wagner. 2019. “The electoral appeal of party strategies in post-industrial societies: when can the Mainstream Left succeed?" The Journal of Politics 81(4):1405-1419.

Alesina, Alberto and Edward Glaeser. 2004. Fighting Poverty in the U.S. and in Europe: A World of Difference. New York: Oxford University Press.

Amat, Francesc, Andreu Arenas, Albert Falcó-Gimeno, and Jordi Muñoz. 2020. "Pandemics meet democracy. Experimental evidence from the COVID-19 crisis in Spain." SocArchiv papers .

Arceneaux, Kevin, Bert N. Bakker, Sara Hobolt, and Catherine E. DeVries. 2020. "Is COVID-19 a Threat to Liberal Democracy?" PsyArXiv .

Ares, Macarena, Reto Bürgisser, and Silja Häusermann. 2021. "Attitudinal polarization towards the redistributiverole of the state in the wake of the COVID-19 crisis." Journal of Elections, Public Opinion and Parties 31:41-55.

Blekesaune, M. 2007. "Economic Conditions and Public Attitudes to Welfare Policies." European Sociological Review 23(3):393-403.

Bol, Damien, Marco Giani, Andre Blais, and Peter Loewen. 2020. "The effect of COVID-19 lockdowns on political support: Some good news for democracy?" European Journal of Political Research .

Brinca, Pedro, Joao B. Duarte, and Miguel Fariae-Castro. 2020. "Is the COVID-19 Pandemic a Supply or a Demand Shock?" Economic Synopses 31.

Busemeyer, Marius R. 2021. "Financing the welfare state in times of extreme crisis: public support for health care spending during the Covid-19 pandemic in Germany." Journal of European Public Policy .

Cavaille, C. and K-S. Trump. 2015. "The Two Facets of Social Policy Preferences.” The Journal of Politics 77(1):146-160.

Dennison, James, Alexander Kustov, and Andrew Geddes. 2021. "Public Attitudes to Immigration in the Aftermath of COVID-19." SSRN .

Duch, Raymond M. and Randolph T. Stevenson. 2008. The Economic Vote: How Political and Economic Institutions Condition Election Results. Cambridge University Press.

Durr, R.H. 1993. “What Moves Policy Sentiment?” American Political Science Review 87(1):58-170. 
Erikson, RS, MB MacKuen, and JA Stimson. 2002. The Macro Polity. Cambridge University Press.

Evans, Geoffrey and James Tilley. 2017. The New Politics of Class: The Political Exclusion of the British Working Class. Oxford University Press.

Fisman, Raymond, Keith Gladstone, Ilyana Kuziemko, and Suresh Naidu. 2020. "Do Americans want to tax wealth? Evidence from online surveys." Journal of Public Economics 188.

Green, Jane and Will Jennings. 2017. The Politics of Competence. Parties, Public Opinion and Voters. Cambridge University Press.

Hale, Thomas, Noam Angrist, Rafael Goldszmidt, Beatriz Kira, Anna Petherick, Toby Phillips, Samuel Webster, Emily Cameron-Blake, Laura Hallas, Saptarshi Majumdar, and Helen Tatlow. 2021. "A global panel database of pandemic policies (Oxford COVID-19 Government Response Tracker).” Nature Human Behaviour 5:529-538.

Heap, Shaun P. Hargreaves, Christel Koop, Konstantinos Matakos, Asli Unan, and Nina Weber. 2021. "We Cannot Disagree Forever! Reality Polarization and Citizens'Post-Pandemic Fiscal Adjustment Preferences." Quantitative Political Economy Research Group (2021-24).

Häusermann, Silja. 2018. "The multidimensional politics of social investment in conservative welfare regimes: family policy reform between social transfers and social investment." Journal of European Public Policy 25(6):862-877.

Imai, Kosuke, Luke Keele, Dustin Tingley, and Teppei Yamamoto. 2011. "Unpacking the Black Box of Causality: Learning About Causal Mechanisms from Experimental and Observational Studies.” American Political Science Review 105(4):765-89.

Iversen, Torben and David Soskice. 2001. "An asset theory of social policy preferences." American Political Science Review 95(4):875-894.

Jones, S.R., S. Carley, and M. Harrison. 2003. "An introduction to power and sample size estimation." Emergency Medicine Journal 20(5):453-458.

Kelly, NJ and PK Enns. 2010. "Inequality and the dynamics of public opinion: the self-reinforcing link between economicinequality and mass preferences." American Journal of Political Science 54(4):855870.

Kenworthy, Lane and Jonas Pontusson. 2005. "Rising Inequality and the Politics of Redistribution in 
Affluent Countries.” Perspectives on Politics 3(3):449-471.

Krupnikov, Yanna and Blake Findley. 2018. The Oxford Handbook of Polling and Survey Methods, chap. Survey Experiments: Managing the Methodological Costs and Benefits. Oxford University Press.

Lewis-Beck, Michael S. and Mary Stegmaier. 2000. "Economic Determinants of Electoral Outcomes." Annual Review of Political Science 3:183-219.

Limberg, Julian. 2020. "What's fair? Preferences for tax progressivityin the wake of the financial crisis." Journal of Public Policy 40:171-193.

Lupu, Noam and Jonas Pontusson. 2011. "The Structure of Inequality and the Politics of Redistribution." American Political Science Review 105(2):316-336.

Margalit, Yotam. 2013. "Explaining Social Policy Preferences: Evidence from the Great Recession." American Political Science Review 107(1):80-103.

Margalit, Yotam. 2019. "Political Responses to Economic Shocks." Annual Review of Political Science 22:277-95.

Meltzer, Allan H. and Scott F. Richard. 1981. “A Rational Theory of the Size of Government.” Journal of Political Economy 89:914-27.

Nadeau, Richard, Vincent Arel-Bundock, and Jean-Francois Daoust. 2019. "Satisfaction with Democracy and the American Dream.” The Journal of Politics 81(3):1080-1084.

Nadeau, Richard, Martial Foucault, and Michael S. Lewis-beck. 2010. "Patrimonial Economic Voting: Legislative Elections in France.” West European Politics 33(6):1261-1277.

Naumann, E., C. Buss, and J. Bähr. 2016. "How Unemployment Experience AffectsSupport for the Welfare State: A Real Panel Approach.” European SociologicalReview 32(1):81-92.

Peyton, Kyle. 2020. "Does Trust in Government Increase Support for Redistribution? Evidence from Randomized Survey Experiments.” American Political Science Review 114(2):596-602.

Rehm, Philipp. 2009. "Risks and Redistribution. An Individual-Level Analysis." Comparative Political Studies 42(7):855-881.

Rehm, Philipp, Jacob S. Hacker, and Mark Schlesinger. 2012. “Insecure Alliances: Risk, Inequality, and Support for the Welfare State.” American Political Science Review 106(2):386-406. 
Reny, Tyler T. and Matt A. Barreto. 2020. "Xenophobia in the time of pandemic: othering, anti-Asian attitudes, and COVID-19." Politics, Groups, and Identities .

Rueda, David. 2017. "Food Comes First, Then Morals: Redistribution Preferences, Parochial Altruism, and Immigration in Western Europe." The Journal of Politics 80(1):225-239.

Stevenson, R.T. 2001. “The Economy and Policy Mood: A Fundamental Dynamic ofDemocratic Politics?" American Journal of Political Science 45(3):620-633.

Stubager, Rune, Michael Lewis-Beck, and Richard Nadeau. 2013. "Reaching for profit in the welfare state: Patrimonial economic voting in Denmark.” Electoral Studies 32(3):438-444.

Tilley, James, Anja Neundorf, and Sara B. Hobolt. 2018. "When the pound in people's pocket matters: how changes to personal financial circumstances affect party choice." The Journal of Politics 80(2):555-569.

Wlezien, Christopher and Stuart Soroka. 2021. "Trends in Public Support for Welfare Spending: How the Economy Matters.” British Journal of Political Science 51:163-180.

Yucesahin, M. Murat and Ibrahim Sirkeci. 2020. "Coronavirus and Migration: Analysis of Human Mobility and the Spread of COVID-19." Migration Letters 17(2):379-398. 


\section{Supplementary Analysis}

\section{Comparing sample characteristics with 2019 British Election Study (BES) data}

To assess the quality and representatives of our survey, we compare key demographic characteristics to the 2019 British Election Study face-to-face survey, which is based on a probability sample based on UK eligible voters and includes 3,946 respondents. ${ }^{12}$ To calculate descriptive statistics for the BES data, we use the population weight [wt_demog].

Table A.1: Sample comparison with 2019 BES

\begin{tabular}{lrr}
\hline & Our sample & BES 2019 \\
\hline Age (mean) & 47.9 & 49.6 \\
Female (\%) & 48.4 & 50.9 \\
White (\%) & 88.3 & 87.1 \\
Highest degree (\%) & & \\
$\quad$ Below secondary & 0.9 & 24.8 \\
Secondary & 49.9 & 35.3 \\
Degree & 49.2 & 39.9 \\
Housing (\%) & & \\
Own - no mortgage & 41.1 & 35.7 \\
Own - mortgage & 27.2 & 33.9 \\
Renting & 31.7 & 30.5 \\
\hline
\end{tabular}

\footnotetext{
12 Data and further details can be accessed via: https://www.britishelectionstudy.com/data-object/ 2019-british-election-study-post-election-random-probability-survey/.
} 


\section{Balance Test: Multi-nominal logistic regression of treatment allocation}

Table A.2: Balance Test: Multi-nominal logistic regression of treatment allocation (reference category: control group)

\begin{tabular}{|c|c|c|c|}
\hline Treatment group: & Economic debacle & Open borders & Health crisis \\
\hline \multirow[t]{2}{*}{ Female } & 0.166 & 0.266 & 0.101 \\
\hline & {$[0.211]$} & [0.213] & {$[0.214]$} \\
\hline \multirow[t]{2}{*}{ Age } & 0.009 & 0.004 & 0.004 \\
\hline & {$[0.008]$} & {$[0.008]$} & {$[0.008]$} \\
\hline \multirow[t]{2}{*}{ Degree } & 0.153 & -0.059 & -0.151 \\
\hline & [0.215] & [0.216] & [0.216] \\
\hline \multirow[t]{2}{*}{ Working } & -0.214 & -0.189 & -0.137 \\
\hline & {$[0.233]$} & {$[0.234]$} & {$[0.233]$} \\
\hline \multirow[t]{2}{*}{ White } & -0.042 & 0.283 & 0.404 \\
\hline & [0.321] & [0.337] & {$[0.350]$} \\
\hline \multirow{2}{*}{ Political interest } & -0.028 & -0.001 & -0.054 \\
\hline & [0.047] & {$[0.048]$} & [0.047] \\
\hline \multirow[t]{2}{*}{ Religious } & 0.013 & 0.130 & 0.123 \\
\hline & [0.204] & [0.205] & [0.204] \\
\hline \multicolumn{4}{|c|}{ Housing (ref: Own - no mortgage) } \\
\hline \multirow[t]{2}{*}{ Own - with mortgage } & $0.562 * *$ & $0.639 * *$ & $0.459 *$ \\
\hline & {$[0.274]$} & {$[0.274]$} & [0.276] \\
\hline \multirow{2}{*}{ Renting } & $0.422 *$ & 0.281 & 0.201 \\
\hline & {$[0.254]$} & {$[0.258]$} & [0.256] \\
\hline \multicolumn{4}{|l|}{ Domicile (ref: Rural) } \\
\hline \multirow[t]{2}{*}{ Small city or sizable town } & 0.161 & -0.020 & -0.309 \\
\hline & {$[0.388]$} & [0.394] & [0.402] \\
\hline \multirow[t]{2}{*}{ Suburban } & $0.466^{* *}$ & 0.139 & -0.065 \\
\hline & {$[0.237]$} & {$[0.235]$} & {$[0.232]$} \\
\hline \multirow[t]{2}{*}{ Urban } & $0.570 *$ & 0.470 & 0.221 \\
\hline & {$[0.298]$} & [0.294] & {$[0.294]$} \\
\hline \multicolumn{4}{|l|}{ Party ID (ref: none) } \\
\hline \multirow[t]{2}{*}{ Conservative } & -0.177 & -0.053 & 0.025 \\
\hline & [0.334] & [0.336] & [0.341] \\
\hline \multirow[t]{2}{*}{ Labour } & -0.265 & -0.238 & 0.039 \\
\hline & [0.335] & [0.340] & {$[0.343]$} \\
\hline \multirow[t]{2}{*}{ Other } & 0.008 & -0.184 & 0.027 \\
\hline & {$[0.358]$} & {$[0.370]$} & {$[0.373]$} \\
\hline \multirow[t]{2}{*}{ Constant } & -0.623 & -0.740 & -0.272 \\
\hline & [0.730] & {$[0.741]$} & {$[0.738]$} \\
\hline \multirow[t]{2}{*}{ Constant } & -0.731 & -0.866 & -0.255 \\
\hline & {$[0.706]$} & {$[0.717]$} & {$[0.711]$} \\
\hline Observations & 880 & 880 & 880 \\
\hline
\end{tabular}

Significance levels: $* * * \mathrm{p}<0.01, * * \mathrm{p}<0.05, * \mathrm{p}<0.1$.

Source: Deltapoll online survey. Note: The table reports logit coefficients and standard errors. 


\section{Impact of treatments on endogenous moderator variables}

Figure A.1: Marginal effects and 95\% confidence intervals of Covid treatments on moderator variables

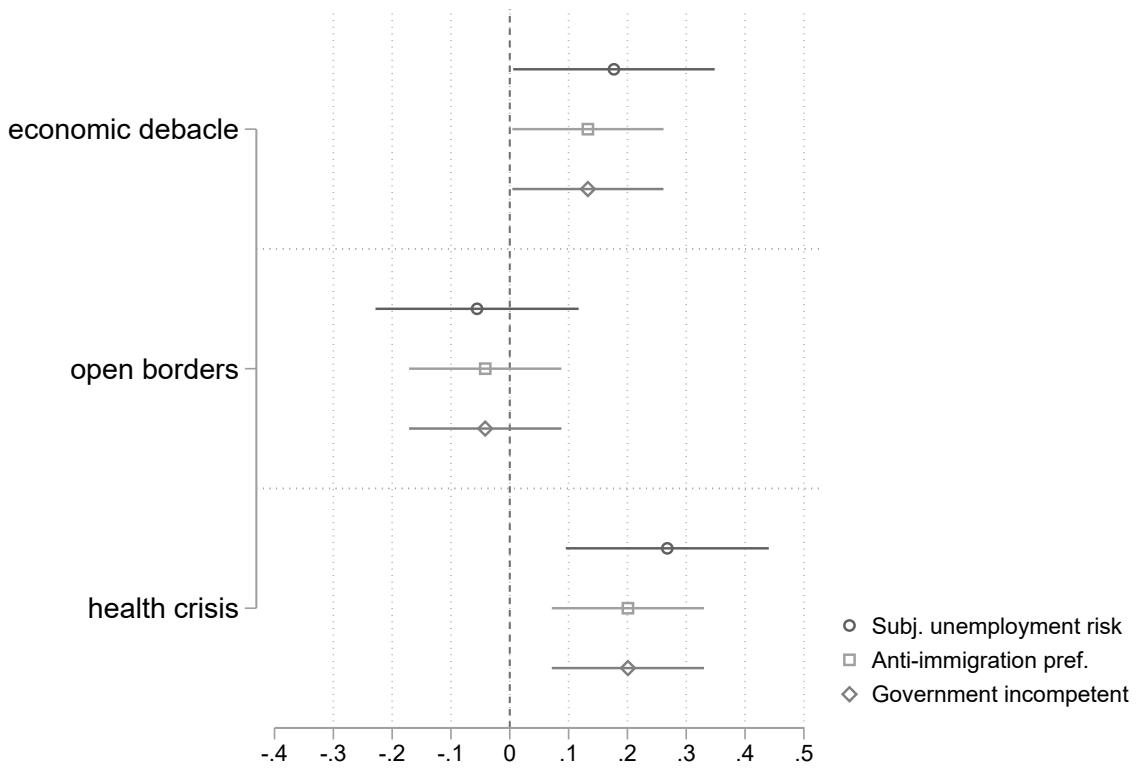

Note: The results are based on linear regressions, controlling for housing and domicile. All outcome variables were standardized to range from 0 to 1 . 


\subsection{Coefficients of main models}

Table A.3: Coefficients of main models

\begin{tabular}{|c|c|c|c|c|c|c|c|c|}
\hline \multirow[t]{2}{*}{ Outcome } & \multicolumn{2}{|c|}{ Spending: unemployment } & \multicolumn{2}{|c|}{ Spending: health } & \multicolumn{2}{|c|}{ Tax progressivity } & \multicolumn{2}{|c|}{ Wealth tax } \\
\hline & M1.1 & M1.2 & M2.1 & M2.2 & M3.1 & M3.2 & M4.1 & M4.2 \\
\hline \multicolumn{9}{|l|}{ Treatment (ref: control) } \\
\hline \multirow[t]{2}{*}{ Economic debacle } & $0.053 * *$ & $0.048 *$ & $0.074 * * *$ & $0.066 * * *$ & $0.039 *$ & 0.030 & -0.007 & -0.006 \\
\hline & {$[0.026]$} & {$[0.025]$} & {$[0.026]$} & {$[0.025]$} & {$[0.023]$} & {$[0.022]$} & {$[0.028]$} & {$[0.028]$} \\
\hline \multirow[t]{2}{*}{ Open borders } & -0.017 & -0.016 & 0.015 & 0.009 & 0.011 & 0.003 & -0.011 & -0.009 \\
\hline & {$[0.026]$} & {$[0.025]$} & [0.027] & {$[0.025]$} & {$[0.023]$} & [0.022] & {$[0.028]$} & {$[0.028]$} \\
\hline \multirow[t]{2}{*}{ Health crisis } & $0.080^{* * *}$ & $0.075^{* * *} *$ & $0.087 * * *$ & $0.075 * * *$ & $0.058 * *$ & $0.049 * *$ & 0.035 & 0.035 \\
\hline & {$[0.026]$} & {$[0.025]$} & {$[0.026]$} & {$[0.025]$} & {$[0.023]$} & {$[0.022]$} & {$[0.028]$} & {$[0.028]$} \\
\hline \multicolumn{9}{|c|}{ Housing (ref: Own - no mortgage) } \\
\hline Own - with mortgage & $\begin{array}{c}-0.001 \\
{[0.023]}\end{array}$ & $\begin{array}{c}0.051 * * \\
{[0.025]}\end{array}$ & $\begin{array}{c}-0.043 * \\
{[0.023]}\end{array}$ & $\begin{array}{c}0.032 \\
{[0.025]}\end{array}$ & $\begin{array}{c}-0.059 * * * \\
{[0.020]}\end{array}$ & $\begin{array}{c}0.021 \\
{[0.022]}\end{array}$ & $\begin{array}{c}0.009 \\
{[0.025]}\end{array}$ & $\begin{array}{c}0.027 \\
{[0.028]}\end{array}$ \\
\hline Renting & $\begin{array}{c}0.069^{* * *} * \\
{[0.022]}\end{array}$ & $\begin{array}{c}0.099 * * * \\
{[0.024]}\end{array}$ & $\begin{array}{c}-0.006 \\
{[0.022]}\end{array}$ & $\begin{array}{c}0.050 * * \\
{[0.024]}\end{array}$ & $\begin{array}{c}-0.004 \\
{[0.020]}\end{array}$ & $\begin{array}{c}0.062^{* * *} * \\
{[0.020]}\end{array}$ & $\begin{array}{c}0.049 * * \\
{[0.024]}\end{array}$ & $\begin{array}{c}0.061 * * \\
{[0.026]}\end{array}$ \\
\hline \multicolumn{9}{|l|}{ Domicile (ref: Rural) } \\
\hline Small city or sizable town & $\begin{array}{c}-0.029 \\
{[0.038]}\end{array}$ & $\begin{array}{c}-0.001 \\
{[0.037]}\end{array}$ & $\begin{array}{c}-0.072 * \\
{[0.038]}\end{array}$ & $\begin{array}{c}-0.018 \\
{[0.037]}\end{array}$ & $\begin{array}{c}-0.064 * \\
{[0.033]}\end{array}$ & $\begin{array}{c}-0.013 \\
{[0.032]}\end{array}$ & $\begin{array}{c}0.036 \\
{[0.040]}\end{array}$ & $\begin{array}{c}0.038 \\
{[0.041]}\end{array}$ \\
\hline Suburban & $\begin{array}{l}-0.008 \\
{[0.022]}\end{array}$ & $\begin{array}{c}0.002 \\
{[0.021]}\end{array}$ & $\begin{array}{c}-0.024 \\
{[0.022]}\end{array}$ & $\begin{array}{c}-0.012 \\
{[0.022]}\end{array}$ & $\begin{array}{c}-0.028 \\
{[0.020]}\end{array}$ & $\begin{array}{c}-0.017 \\
{[0.019]}\end{array}$ & $\begin{array}{c}0.009 \\
{[0.024]}\end{array}$ & $\begin{array}{c}0.006 \\
{[0.024]}\end{array}$ \\
\hline Urban & $\begin{array}{c}-0.011 \\
{[0.027]}\end{array}$ & $\begin{array}{c}0.024 \\
{[0.026]}\end{array}$ & $\begin{array}{c}-0.085 * * * \\
{[0.027]}\end{array}$ & $\begin{array}{c}-0.031 \\
{[0.027]}\end{array}$ & $\begin{array}{c}-0.077 * * * \\
{[0.023]}\end{array}$ & $\begin{array}{c}-0.022 \\
{[0.023]}\end{array}$ & $\begin{array}{c}0.022 \\
{[0.028]}\end{array}$ & $\begin{array}{c}0.023 \\
{[0.029]}\end{array}$ \\
\hline Female & & $\begin{array}{c}-0.043^{* *} * \\
{[0.019]}\end{array}$ & & $\begin{array}{c}-0.018 \\
{[0.019]}\end{array}$ & & $\begin{array}{c}0.014 \\
{[0.017]}\end{array}$ & & $\begin{array}{c}-0.01 \\
{[0.021]}\end{array}$ \\
\hline Age & & $\begin{array}{c}0.003^{* * * *} \\
{[0.001]}\end{array}$ & & $\begin{array}{c}0.004 * * * \\
{[0.001]}\end{array}$ & & $\begin{array}{c}0.005^{* * *} * \\
{[0.001]}\end{array}$ & & $\begin{array}{c}0.002 * * \\
{[0.001]}\end{array}$ \\
\hline Degree & & $\begin{array}{c}0.005 \\
{[0.020]}\end{array}$ & & $\begin{array}{c}0.011 \\
{[0.020]}\end{array}$ & & $\begin{array}{c}-0.027 \\
{[0.017]}\end{array}$ & & $\begin{array}{c}0.008 \\
{[0.022]}\end{array}$ \\
\hline Working & & $\begin{array}{c}-0.051 * * \\
{[0.021]}\end{array}$ & & $\begin{array}{c}-0.045^{* *} \\
{[0.021]}\end{array}$ & & $\begin{array}{c}-0.012 \\
{[0.018]}\end{array}$ & & $\begin{array}{c}-0.015 \\
{[0.024]}\end{array}$ \\
\hline White & & $\begin{array}{c}0.093 * * * \\
{[0.031]}\end{array}$ & & $\begin{array}{c}0.093 * * * \\
{[0.031]}\end{array}$ & & $\begin{array}{c}0.038 \\
{[0.027]}\end{array}$ & & $\begin{array}{c}0.05 \\
{[0.034]}\end{array}$ \\
\hline Political interest & & $\begin{array}{c}0.004 \\
{[0.004]}\end{array}$ & & $\begin{array}{c}-0.005 \\
{[0.004]}\end{array}$ & & $\begin{array}{c}0.010 * * * \\
{[0.004]}\end{array}$ & & $\begin{array}{c}0.011 * * \\
{[0.005]}\end{array}$ \\
\hline Religious & & $\begin{array}{c}-0.065^{* * *} * \\
{[0.019]}\end{array}$ & & $\begin{array}{c}-0.039 * * \\
{[0.019]}\end{array}$ & & $\begin{array}{c}-0.041^{* *} \\
{[0.016]}\end{array}$ & & $\begin{array}{c}-0 \\
{[0.021]}\end{array}$ \\
\hline \multicolumn{9}{|l|}{ Party ID (ref: none) } \\
\hline Conservative & & $\begin{array}{c}-0.105^{* * *} * \\
{[0.030]}\end{array}$ & & $\begin{array}{c}-0.062^{* *} \\
{[0.030]}\end{array}$ & & $\begin{array}{c}-0.124 * * * \\
{[0.026]}\end{array}$ & & $\begin{array}{c}-0.076 * * \\
{[0.034]}\end{array}$ \\
\hline Labour & & $\begin{array}{l}0.053 * \\
{[0.030]}\end{array}$ & & $\begin{array}{c}0.062 * * \\
{[0.031]}\end{array}$ & & $\begin{array}{c}-0.04 \\
{[0.027]}\end{array}$ & & $\begin{array}{c}0.068 * * \\
{[0.034]}\end{array}$ \\
\hline Other & & $\begin{array}{c}0.037 \\
{[0.033]}\end{array}$ & & $\begin{array}{c}-0.01 \\
{[0.033]}\end{array}$ & & $\begin{array}{c}-0.058 * * \\
{[0.029]}\end{array}$ & & $\begin{array}{c}0.011 \\
{[0.037]}\end{array}$ \\
\hline Constant & $\begin{array}{c}0.418^{* * * *} \\
{[0.024]}\end{array}$ & $\begin{array}{c}0.233^{* * * *} \\
{[0.068]}\end{array}$ & $\begin{array}{c}0.610 * * * \\
{[0.025]}\end{array}$ & $\begin{array}{c}0.350 * * * \\
{[0.068]}\end{array}$ & $\begin{array}{c}0.727 * * * \\
{[0.022]}\end{array}$ & $\begin{array}{c}0.417 * * * \\
{[0.059]}\end{array}$ & $\begin{array}{c}0.622 * * * \\
{[0.026]}\end{array}$ & $\begin{array}{c}0.413 * * * \\
{[0.076]}\end{array}$ \\
\hline $\begin{array}{l}\text { Observations } \\
\mathrm{R}^{2}\end{array}$ & $\begin{array}{c}880 \\
0.034\end{array}$ & $\begin{array}{c}880 \\
0.145\end{array}$ & $\begin{array}{c}880 \\
0.035\end{array}$ & $\begin{array}{c}880 \\
0.146\end{array}$ & $\begin{array}{c}880 \\
0.034\end{array}$ & $\begin{array}{l}880 \\
0.17\end{array}$ & $\begin{array}{c}880 \\
0.011\end{array}$ & $\begin{array}{l}880 \\
0.06\end{array}$ \\
\hline
\end{tabular}

Significance levels: *** $\mathrm{p}<0.01, * * \mathrm{p}<0.05, * \mathrm{p}<0.1$.

Source: Deltapoll online survey. Note: The table reports linear regression coefficients and standard errors. 


\subsection{Replication in the US}

Figure A.2: Regression coefficients and 95\% confidence intervals of Covid treatments on welfare attitudes

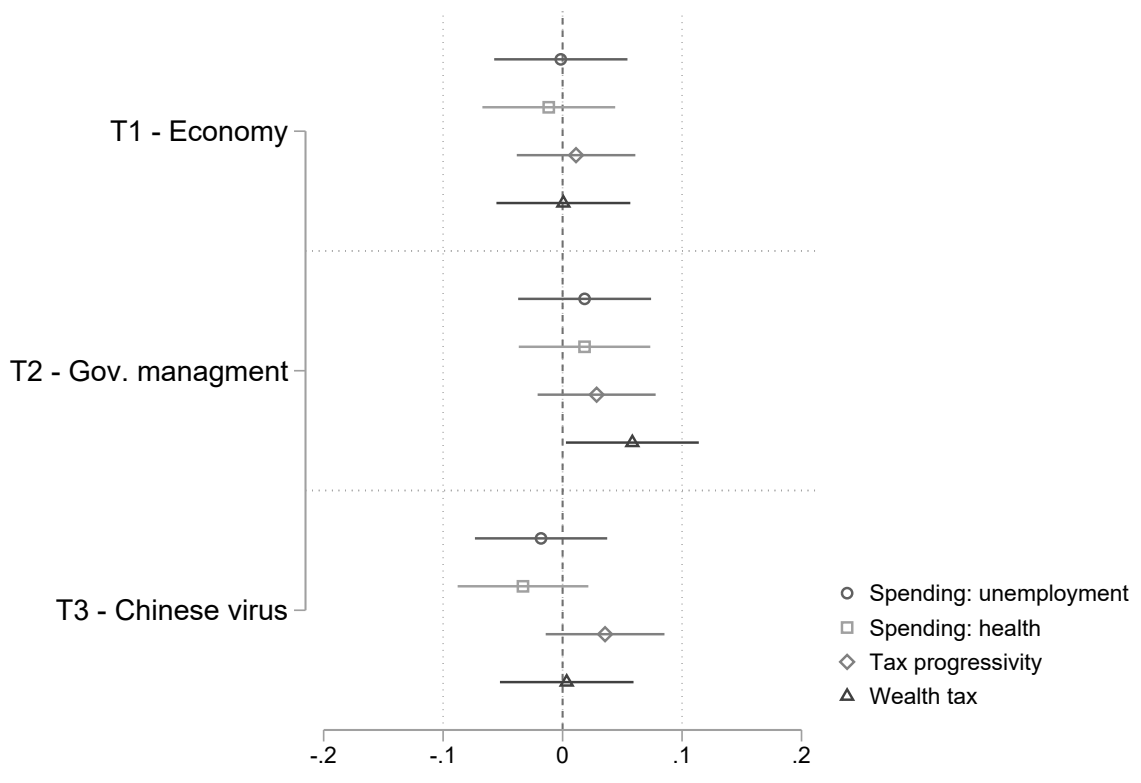

Note: The results are based on linear regressions, controlling for ethnicity and religion. All outcome variables were standardized to range from 0 to 1. 
Figure A.3: Marginal effects of economic prime and 95\% confidence intervals on welfare attitudes by income
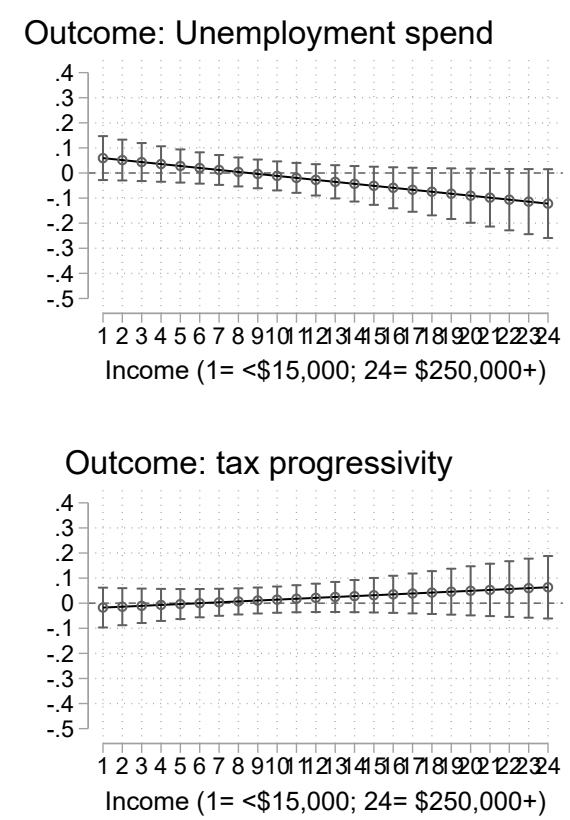

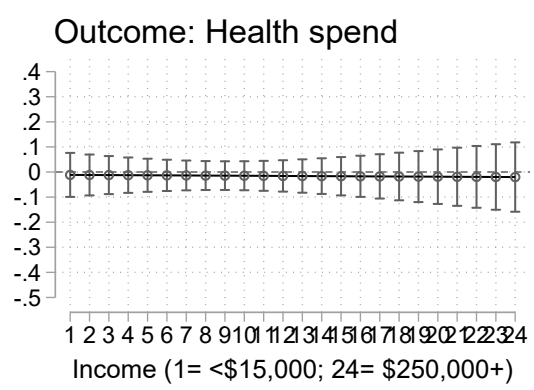

Outcome: wealth tax

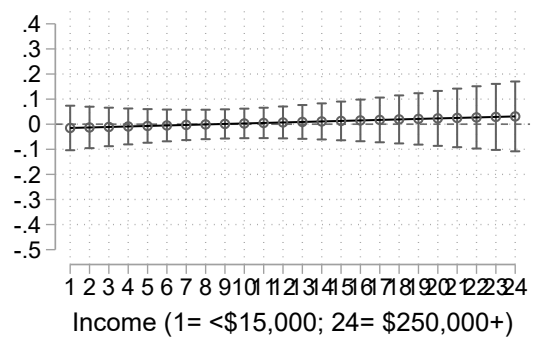

Note: The results are based on linear regressions, controlling for ethnicity and religion. All outcome variables were standardized to range from 0 to 1. 
Figure A.4: Marginal effects of economic prime and 95\% confidence intervals on welfare attitudes by unemployment risk
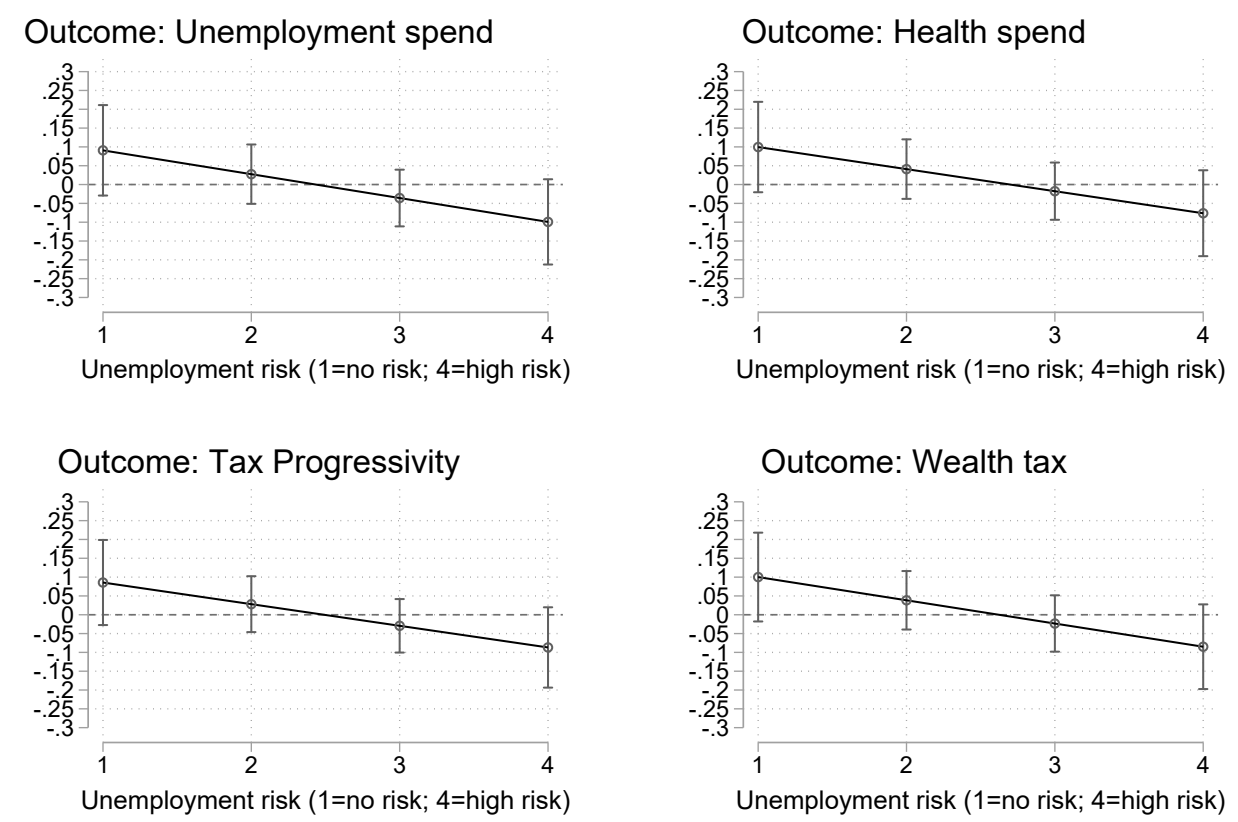

Note: The results are based on linear regressions, controlling for ethnicity and religion. All outcome variables were standardized to range from 0 to 1. 


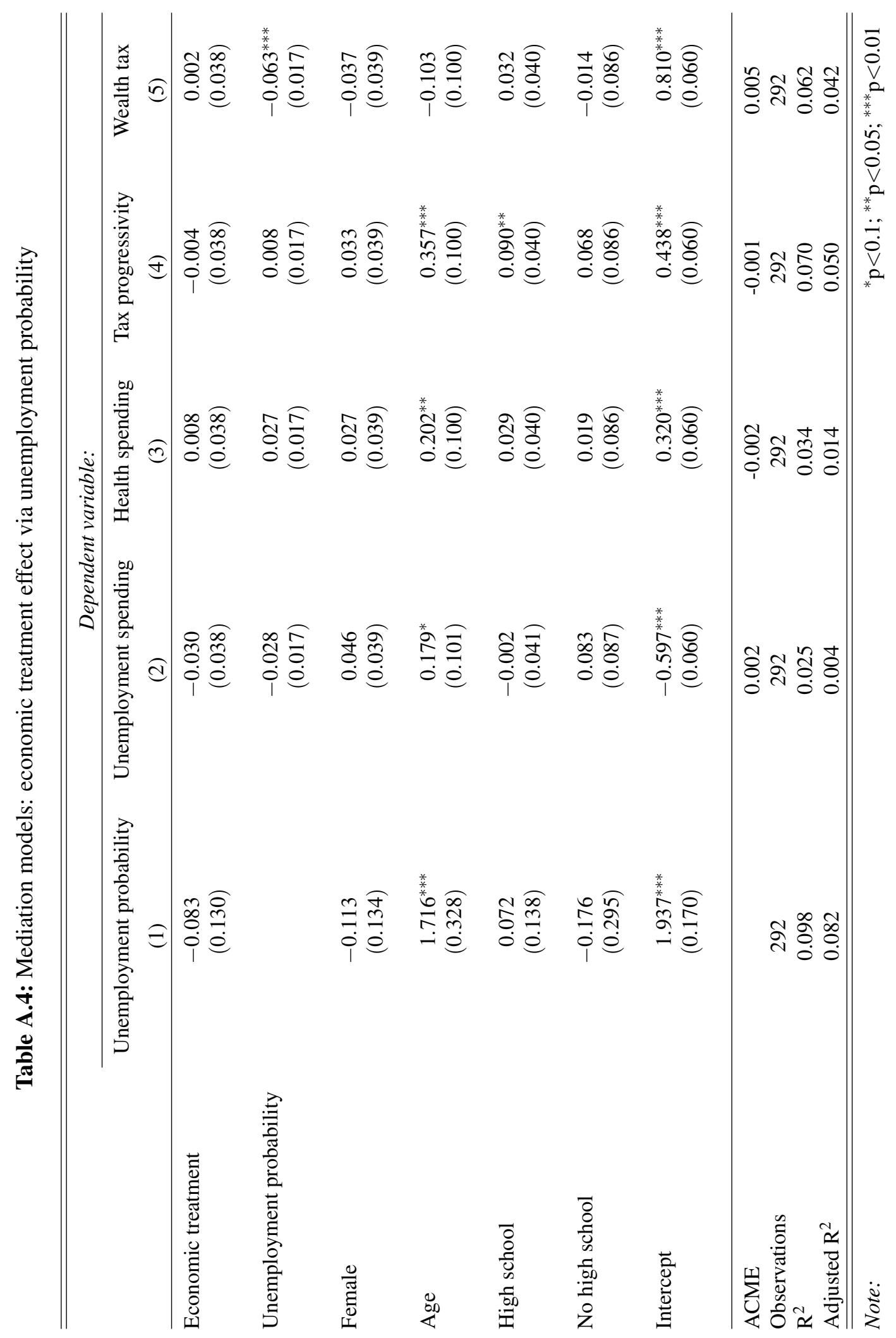




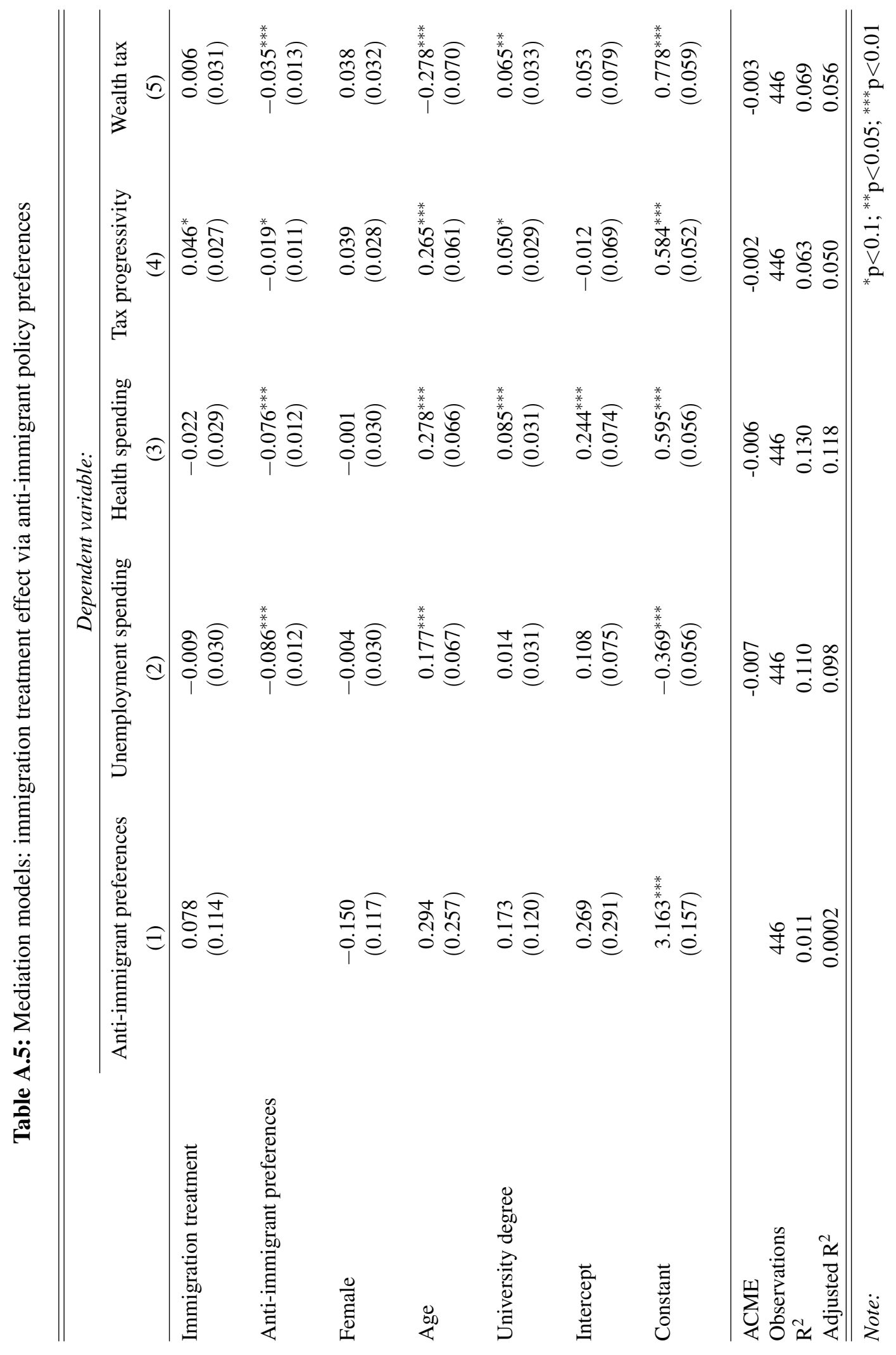


Table A.6: Interaction between experimental treatments and partisanship

\begin{tabular}{|c|c|c|c|c|}
\hline & $\begin{array}{c}\text { M1 } \\
\text { Unemp. Spend }\end{array}$ & $\begin{array}{c}\text { M2 } \\
\text { Health spend. }\end{array}$ & $\begin{array}{c}\text { M3 } \\
\text { Tax progressiv. }\end{array}$ & $\begin{array}{c}\text { M4 } \\
\text { Wealth tax }\end{array}$ \\
\hline \multicolumn{5}{|l|}{ Treatment (ref: Control) } \\
\hline $\mathrm{T} 1$ - Economic & $\begin{array}{c}0.025 \\
{[0.051]}\end{array}$ & $\begin{array}{c}0.061 \\
{[0.051]}\end{array}$ & $\begin{array}{c}0.061 \\
{[0.048]}\end{array}$ & $\begin{array}{c}0.071 \\
{[0.052]}\end{array}$ \\
\hline $\mathrm{T} 2$ - Health crisis & $\begin{array}{c}0.052 \\
{[0.051]}\end{array}$ & $\begin{array}{c}0.060 \\
{[0.051]}\end{array}$ & $\begin{array}{c}0.068 \\
{[0.047]}\end{array}$ & $\begin{array}{c}0.060 \\
{[0.051]}\end{array}$ \\
\hline T3 - Open borders & $\begin{array}{c}0.019 \\
{[0.050]}\end{array}$ & $\begin{array}{c}0.099 * * \\
{[0.050]}\end{array}$ & $\begin{array}{c}0.119 * * \\
{[0.047]}\end{array}$ & $\begin{array}{l}0.102 * * \\
{[0.051]}\end{array}$ \\
\hline \multicolumn{5}{|c|}{ Partisanship (ref: Independent) } \\
\hline Democrat & $\begin{array}{c}0.113^{* *} \\
{[0.048]}\end{array}$ & $\begin{array}{c}0.157 * * * \\
{[0.048]}\end{array}$ & $\begin{array}{l}0.107 * * \\
{[0.045]}\end{array}$ & $\begin{array}{c}0.246 * * * \\
{[0.049]}\end{array}$ \\
\hline Republican & $\begin{array}{c}-0.122^{* *} * \\
{[0.050]}\end{array}$ & $\begin{array}{c}0.019 \\
{[0.049]}\end{array}$ & $\begin{array}{c}0.029 \\
{[0.046]}\end{array}$ & $\begin{array}{c}0.042 \\
{[0.050]}\end{array}$ \\
\hline \multicolumn{5}{|l|}{$\mathrm{T} 1$ - Economic $\mathrm{x}$} \\
\hline Democrat & $\begin{array}{c}-0.028 \\
{[0.068]}\end{array}$ & $\begin{array}{c}-0.067 \\
{[0.068]}\end{array}$ & $\begin{array}{c}-0.046 \\
{[0.063]}\end{array}$ & $\begin{array}{c}-0.104 \\
{[0.069]}\end{array}$ \\
\hline Republican & $\begin{array}{c}-0.05 \\
{[0.071]}\end{array}$ & $\begin{array}{c}-0.159^{* *} \\
{[0.070]}\end{array}$ & $\begin{array}{l}-0.081 \\
{[0.065]}\end{array}$ & $\begin{array}{c}-0.094 \\
{[0.071]}\end{array}$ \\
\hline \multicolumn{5}{|l|}{$\mathrm{T} 2$ - Health crisis $\mathrm{x}$} \\
\hline Democrat & $\begin{array}{c}-0.039 \\
{[0.069]}\end{array}$ & $\begin{array}{c}-0.016 \\
{[0.068]}\end{array}$ & $\begin{array}{c}-0.04 \\
{[0.063]}\end{array}$ & $\begin{array}{c}-0.049 \\
{[0.068]}\end{array}$ \\
\hline Republican & $\begin{array}{c}-0.057 \\
{[0.070]}\end{array}$ & $\begin{array}{c}-0.140 * * \\
{[0.070]}\end{array}$ & $\begin{array}{c}-0.076 \\
{[0.065]}\end{array}$ & $\begin{array}{c}0.024 \\
{[0.071]}\end{array}$ \\
\hline \multicolumn{5}{|l|}{$\mathrm{T} 3$ - Open borders $\mathrm{x}$} \\
\hline Democrat & $\begin{array}{c}-0.077 \\
{[0.067]}\end{array}$ & $\begin{array}{c}-0.164 * * \\
{[0.067]}\end{array}$ & $\begin{array}{c}-0.102 \\
{[0.063]}\end{array}$ & $\begin{array}{l}-0.128^{*} \\
{[0.068]}\end{array}$ \\
\hline Republican & $\begin{array}{c}-0.04 \\
{[0.069]}\end{array}$ & $\begin{array}{c}-0.241^{* * *} \\
{[0.069]}\end{array}$ & $\begin{array}{c}-0.134 * * \\
{[0.064]}\end{array}$ & $\begin{array}{c}-0.170 * * \\
{[0.070]}\end{array}$ \\
\hline \multicolumn{5}{|l|}{ Ethnicity (ref: White) } \\
\hline Black & $\begin{array}{c}-0.028 \\
{[0.032]}\end{array}$ & $\begin{array}{c}-0.081 * * * \\
{[0.031]}\end{array}$ & $\begin{array}{c}-0.132 * * * \\
{[0.030]}\end{array}$ & $\begin{array}{c}-0.03 \\
{[0.032]}\end{array}$ \\
\hline Hispanic & $\begin{array}{c}-0.021 \\
{[0.035]}\end{array}$ & $\begin{array}{c}-0.051 \\
{[0.035]}\end{array}$ & $\begin{array}{c}-0.04 \\
{[0.033]}\end{array}$ & $\begin{array}{c}-0.029 \\
{[0.035]}\end{array}$ \\
\hline Other & $\begin{array}{c}-0.05 \\
{[0.047]}\end{array}$ & $\begin{array}{c}-0.108^{* *} \\
{[0.048]}\end{array}$ & $\begin{array}{c}-0.104 * * \\
{[0.044]}\end{array}$ & $\begin{array}{c}-0.068 \\
{[0.046]}\end{array}$ \\
\hline \multicolumn{5}{|c|}{ Religion (ref: Rel. + attend) } \\
\hline Religious + not attend & $\begin{array}{l}0.044 * \\
{[0.024]}\end{array}$ & $\begin{array}{c}0.101 * * * \\
{[0.024]}\end{array}$ & $\begin{array}{c}0.112 * * * \\
{[0.022]}\end{array}$ & $\begin{array}{l}-0.046^{*} \\
{[0.024]}\end{array}$ \\
\hline Not religious & $\begin{array}{l}0.060 * * \\
{[0.025]}\end{array}$ & $\begin{array}{c}0.101 * * * \\
{[0.025]}\end{array}$ & $\begin{array}{c}0.115 * * * \\
{[0.024]}\end{array}$ & $\begin{array}{l}-0.035 \\
{[0.026]}\end{array}$ \\
\hline Constant & $\begin{array}{c}-0.605^{* * *} * \\
{[0.040]}\end{array}$ & $\begin{array}{c}0.409 * * * \\
{[0.040]}\end{array}$ & $\begin{array}{c}0.577 * * * \\
{[0.037]}\end{array}$ & $\begin{array}{c}0.542 * * * \\
{[0.041]}\end{array}$ \\
\hline Observations & 986 & 993 & 1,006 & 999 \\
\hline $\mathrm{R}^{2}$ & 0.11 & 0.12 & 0.08 & 0.09 \\
\hline
\end{tabular}

Significance levels: $* * * \mathrm{p} \leq 0.01, * * \mathrm{p} \leq 0.05, * \mathrm{p} \leq 0.1$. Source: Deltapoll online survey. Note: The table reports coefficients and standard errors. The results are based on linear regressions. All outcome variables were standardized to range from 0 to 1 . 